\title{
Veje væk fra Tidsholm
}

\section{Erindringer fra Tønder-egnen i 1950'erne}

\author{
af Thomas Petersen
}

Årene efter Anden Verdenskrig bød på massive forandringer for befolkningen på landet. Landbruget blev mekaniseret og effektiviseret, og bedrifterne blev færre og større. Valget stod mellem at følge udviklingen, investere i ny jord og maskiner, eller fortsætte som hidtil - og leve med de afsavn, dette valg indebar. Thomas Petersen, der i 1947 flyttede til Tidsholm øst for Tønder, fortæller her sin historie om livet som dreng og ung mand på en gård, hvor revolutionen ikke slog igennem, og hvor traktorer, strøm, telefon og rindende vand aldrig eller meget sent blev en del af hverdagen. Samtidig er Thomas Petersens erindringer også historien om en tid, hvor ungdommen fik mulighed for at bryde den sociale arv og på godt og ondt gå nye veje - væk fra det statiske bondesamfund.

Digteren og journalisten Thorkild Hansen skriver et sted, at de fleste mennesker inde i sig selv bærer et billede af barndommens kyst. Mens alle livets andre indtryk fortoner sig og slettes ud, bliver dette billede stærkere og stærkere. Sådan har jeg det nu i en alder af sluttresserne. Indtryk, oplevelser og begivenheder, der i dag er mere end 50 år gamle, dukker oftere og oftere op i erindringen - hver gang med nye detaljer og sammenhænge. De trænger sig på, de vil ud, de vil have ord sat på og de vil sættes i system.

Som faghistoriker er jeg mig fuldt bevidst om, at erindringer ikke udtrykker det, der skete, men det som forfatteren erindrer, eller det, han ønsker erindret. Der er naturligvis tale om en hårfin grænse, som helt berettiget har fået nogle historikere til at tove med at bruge personlige overleveringer som historiske kilder. Nærværende erindringer er heller ikke skrevet af teenagedrengen Thomas, men derimod af en mand i sin tredje alder, der kigger tilbage på sin barndom og ungdom. Til gengæld håber jeg, at afstanden i tid bevirker, at hvad erindringerne måtte mangle $\mathrm{i}$ præcision og $\mathrm{i}$ detaljen, har de vundet i perspektiv ved at blive set $i$ lyset af forfatterens senere erhvervede viden og erfaring.

Det er vel i bund og grund et banalt, men alligevel evigt aktuelt 
spørgsmål, hvad der bestemmer ens livsbane. Kan den forberedes og planlægges eller er den i sidste ende en tilfældig række af ligeså tilfældige enkelt-tildragelser? Svaret er vel som i så mange andre sammenhænge et både-og. Grundstrukturen i livsforløbet kan planlægges, men detaljerne bestemmes af, hvordan denne grundstruktur kan forenes med eller tilpasses den virkelighed, som det enkelte individ er en del af. Jeg havde allerede i mellemskolen, inspireret af en engageret lærer, fået interesse for historie - en interesse, der i gymnasiet udviklede sig til et ønske om i fremtiden at beskæftige mig med faget. Men hvordan denne beskæftigelse mere specifikt skulle manifestere sig - ja, det skulle vise sig at være en helt anden historie.

Egentlig skulle jeg slet ikke skrive erindringer. Jeg har jo slet ikke det rigtige stof. Min barndom er ingen sællert. Den rummer hverken skilsmisser, drabelige retsopgør, økonomisk sammenbrud, vold eller misbrug af nogen slags - med andre ord ingen af de ingredienser, der er så hyppige i det hav af barndomserindringer, der som en tsunami oversvømmer nutidens bogmarked.

Jeg plejer at kalde 1950'erne for årtiet i venteposition. I Danmark slikkede og reparerede årtiet blot de forholdsvist overfladiske sår fra besættelsesårene - overfladiske i forhold til i hvert fald de krigsdeltagende lande, men også i forhold til andre besatte lande som f.eks. Holland og Norge. Men økonomisk, socialt og kulturelt afventede årtiet noget nyt - alene af den grund, at det gamle var blevet nedslidt som følge af verdenskrigens rædsler. Og det samtidig med, at verdenskrigens teknologiske landvindinger sammen med efterkrigstidens Marshall-hjælp varslede øget velfærd og medfølgende nybrud på alle livets områder. Sagt med andre ord lå alle de nybrud, der realiseredes i det følgende årti, latente allerede i 1950'erne.

Opbrud og nybrud i det sociale mønster. Kvinderne, der forlod kødgryderne og barneværelset til fordel for en plads - heltids eller deltids - på arbejdsmarkedet, og som oplevede en hidtil uset frihed $\mathbf{i}$ valgmuligheder. Opbrud i det økonomiske system. Velfærdsstaten, der blev født og fremkaldte såvel tilhængere som modstandere, men som sammenlagt oplevedes som et gode og som et værdifuldt socialt sikkerhedsnet. Opbrud i uddannelsesmønstret - velfærdsstatens børn, der uanset social arv og økonomiske forhold skulle have så megen uddannelse som muligt - koste hvad det ville. Opbrud i kulturmønstret - modernismen, der stillede spørgsmål til og forkastede de gængse litterære og kunstneriske former og normer samtidig med, 
at nye blev proklameret og afprøvet - sommetider ud i absurditeten. Opbrud i det moralske mønster - det traditionelle familiemønster kom under voldsomt pres, bl.a. som følge af mange nye berøringsflader i det arbejdsmæssige og sociale liv. Men også som følge af kvindernes øgede økonomiske selvstændighed og påfølgende uafhængighed. P-pillen giorde dem endvidere fri af fortidens evindelige frygt for uønsket graviditet. Moderniteten bankede med andre ord på i alle samfundsmæssige og menneskelige relationer og gav rig næring til moderne erindringsskrivning.

Jeg husker min barndom som både tryg og god. Sammen med mine forældre var jeg så heldig at indgå i et fællesskab, hvor arbejde og fritid naturligt flød ud i ét. Sådan var livet på en mindre landbrugsejendom i 1950'erne uden fremmed hjælp. Når jeg cyklede hjem fra skole om foråret eller efteråret, vidste jeg, at der hjemme på marken gik min far og så frem til, at jeg afløste ham bag hestene. Eller når der om foråret skulle køres møg ud fra møddingen, eller møget skulle spredes ud over markerne fra de bunker, som det var læsset af i. Eller når arbejdskraften ved roehakningen kunne fordobles, når jeg kom hjem, fik skiftet tøj og fik gang i en hakker mere. Eller når neg skulle sættes i skok, køres hjem i laden eller sættes i stak. Og om efteråret, når roerne skulle aftoppes, tages op og køres hjem i roekulen.

Jeg oplevede egentlig det hele som en ganske naturlig ting - selv om det, indrømmet, sommetider var træls. Men jeg kendte jo ikke andet. Årstidernes skiften var det evige signal om, at noget nyt $\mathrm{i}$ landbrugsbedriften bankede på. At man var nået til et nyt punkt $i$ livets og årets evige cyklus. Intet under, at bønder altid har været konservative - ikke i partipolitisk betydning, men i grundindstilling til livet og dets tilskikkelser.

Men jeg skal ikke skjule, at jeg af og til oplevede det som et pres hurtigst muligt at skulle hjem efter skole, når jeg hørte kammerater i Tønder fortælle om alle de gøremål, som de havde gang i efter skoletid. Denne klagesang skal absolut ikke forklejne, at jeg sammenlagt kun husker en god og tryg barndom. Mine forældre - kan jeg se nu - gav mig alle de muligheder, som deres virkelighed rummede og betingede. De gav gennem deres egne eksempler nogle klare pejlemærker for, hvordan man skulle gebærde sig, men aldrig med løftede pegefingre eller direkte forbud. De opstillede ingen nationale, religiøse eller moralske forskrifter eller forventninger. De gav mig alle muligheder for at fortsætte skolegangen lige til studentereksamen, og de gav mig fuld fri- 
hed i valg af videre uddannelse. Selvfølgelig ville min far gerne have set mig overtage gården og følge $i$ hans fodspor som landmand. Alt andet ville have været unaturligt - tiden taget $i$ betragtning. Han kunne jo ikke vide, hvilke omvæltninger det traditionelle og gennem århundreder nedarvede landbrugssamfund snart ville blive udsat for. Desuden var han selv ud af en familie, hvor sønnen i generationer havde fulgt faderen på gården. Men da min far ret hurtigt konstaterede, at jeg ikke så godt kunne lide at få beskidte fingre, opgav han stiltiende denne ambition eller gemte den i hukommelsens sidefiler.

Selvfølgelig ville han som det næstbedste gerne have set mig blive skolelærer fra Tønder Statsseminarium og bagefter få ansættelse et sted i nærmiljøet. Men han støttede mig alligevel hele vejen, selv om jeg nok skuffede ham i disse ønsker. Da det gik op for mine forældre, at jeg efter aftjent værnepligt ville studere på Aarhus Universitet, accepterede de det. Men med den tilføjelse, at de ikke var i stand til at støtte mig økonomisk på anden måde end med en pakke i ny og næ. Jeg er sikker på, at der i denne tilføjelse ikke lå nogen form for trussel. Blot var de usikre på den tilværelse og det lange studium, som jeg kastede mig ud i, og som de følte lå helt udenfor deres hjælps muligheder.1nb

\section{Opbrud i 1947}

Min opvækst i skolealderen fandt sted på et husmandssted med 30 tønder ikke særlig god jord, beliggende ved jernbanelinjen TønderTinglev, nærmere bestemt 300 meter nord for den og mellem stationerne Jejsing og Rørkær. Tiden var de sidste år i 1940'erne og de første syv af 1950'erne. Det vil sige en periode, hvor dansk landbrug måtte beslutte sig for modernisering og mekanisering, inklusive den gældsætning, denne proces uvægerligt medførte - eller også at lade stå til, eventuelt suppleret med den ene ægtefælles arbejde udenfor hjemmet. For mange familier i det sønderjyske blev begrebet Danfoss ensbetydende med en supplerende indkomst - som regel hjembragt af manden fra industrieventyret i Nordborg på Als. Danfoss søgte til stadighed arbejdskraft, ikke mindst efter at virksomheden i 1952 var begyndt at producere radiatortermostater. Og jeg husker tydeligt, hvor ofte Danfoss blev nævnt i familiesnakken ved sammenkomster. Virksomheden blev i den sydlige del af Sønderjylland katalysator i den udvikling fra selvstændig landmand til industriarbejder, som tusinder af landbofamilier oplevede $\mathrm{i}$ de år. 
Mine forældre valgte en tredje vej: De forsegte at klare sig med udbyttet af deres 30 tønder land, suppleret med et varieret husdyrhold $i$ form af køer, svin og høns. Dertil en frugthave med 30 Cox Orange-æbletræer, aspargesdyrkning, slagtehøns og hvad der ellers kunne være af Nebengeschäft. Ferguson-traktoren, der blev så almindelig på små gårde i 1950'erne, var der ikke råd til, så husdyrholdet var udover de nævnte også to arbejdsheste. Prisen for den vej, mine forældre valgte, var manglende modernisering og udvikling.

Fremmed hjælp var der heller ikke råd til, så de første år arbejdede min mor også med i stald og på mark - malkningen med håndkraft var mine forældre som regel fælles om. Når de en sjælden gang var på besøg et eller andet sted eller skulle noget andet ekstraordinært, tog jeg mig også af malkningen og det øvrige staldarbejde. Jeg var ikke vild med at malke, men jeg husker tydeligt dette helt specielle arbejde. Den dumpe lyd af den første mælk, der sprøjtede ned i den tomme spand mellem mine knæ. De første skvæt, der klingede mod blikspandens bund, for så at afløses af en cremet hvislen, efterhånden som niveauet i spanden steg. Bobler blomstrede op til overfladen, mens skummet changerede i gult af sød fløde, og den varme duft af frisk mælk fyldte næseborene. Panden, der blev presset ind mod koens lyske, og pelsens glatte hår, der kunne mærkes mod huden. Varmen strålede ud fra den store dyrekrop, mens der fra koens indre kunne høres en dump rumlen, stammende fra mavens komplicerede maskineri - $\mathrm{i}$ konstant aktivitet med at nedbryde græs og kraftfoder til fløde og mælk. Det var ikke altid, koen havde lyst til at stå stille. Eller man kunne være heldig pludselig at få en busket og måske møgbeskidt kohale i nakken - enten, fordi denne handling nu lige passede koens temperament, eller fordi et eller andet dyr stak eller på anden måde generede hende. Men det var en lykke at tage en slurk af den nymalkede mælk.

Efterhånden som jeg voksede til, det vil sige fra slutningen af 1940 'erne, deltog jeg ved siden af skolearbejdet mere og mere i det praktiske arbejde i stalden og på marken derhjemme. Hele dette arrangement var kun farbart, så længe jeg, der var enebarn, boede hjemme og derfor kunne hjælpe til i bedriften. Da jeg blev student i 1957, besluttede mine forældre at sælge gården, udskifte jorden med asfalten, flytte til Tønder og investere provenuet ved salget $i$ dels et hus, dels i en sygehuskiosk med monopollignende status og beliggende lige overfor hospitalet. Huset var Vidågade 21, en tre-etages ejendom, hvor den lange smalle have gik direkte ned til ån. Mine forældre boede selv i stueeta- 
Det var ganske almindeligt $i 1950^{\prime}$ erne, at en luft fotograf tog billeder af gårdene - uden at sporge om lov, forstås. Så kom han rundt og falbod resultatet -og vi købte naturligvis et billede. Der var noget nyt og flot over således at se sit hjem ovenfra. Foran stuehuset frugtplantagen med flere forskellige ablesorter - men flest Cox Orange. For enden af staldbygningen maskin- og redskabsrum. Min far satte stor pris på, at al jorden var placeret omkring gården - $i$ modsætning til, hvad tilfældet havde været $i$ Alslevkro. Foto i privateje.

gen, mens der var lejere på de andre etager. Da min far døde tre år senere, solgte min mor huset og flyttede som lejer op på første sal.

Der var intet i min familiemæssige eller sociale baggrund, der pegede på, at jeg skulle gå den boglige vej. At jeg skulle blive en social mønsterbryder - for at tale i moderne politisk og sociologisk jargon. Ingen $\mathrm{i}$ hverken min fars eller min mors familie havde gået i mellemskolen eller taget studentereksamen. Der var heller intet, der pegede på, at Ruslands historie og det russiske sprog gennem mere end 40 år skulle komme til at udfylde, først en stor del af mit soldaterliv, og dernæst størstedelen af mit studie- og professionelle arbejdsliv. $\mathrm{Og}$ alligevel er der et par ting, som i bakspejlet - ganske vist med megen god vilje og i bagklogskabens klare lys - kan trække en linje mellem min barndom på landet uden indlagt elektricitet og langt fra alting $\mathrm{i}$ 1950'erne og det store ukendte og derfor mystiske Rusland mod øst: 
Fra min meget tidlige barndom kan jeg huske min far gang på gang understrege, at han - og det var han naturligvis ikke alene om - efter tyskernes nederlag ved Stalingrad i vinteren 1942-43 havde været overbevist om, at Hitler nu ville tabe krigen. Den russiske vinter var for mægtig en modstander for selv den tyske krigsmaskine, som den havde været det for Napoleon. For det andet kan jeg huske, at min far efter at have set billeder fra møderne mellem de tre store - det vil sige Churchill, Roosevelt og Stalin - var sikker på, at han af Stalins hele attitude $i$ forhold til de andre kunne se, at sovjetlederen egentlig var ligeglad med de andre og med de beslutninger, de tre havde forhandlet sig frem til.

For det tredje havde min far en gang fundet et nydeligt lommeur, forsynet med kæde og låg, i en sæk foderkorn, der angiveligt skulle være kommet fra Rusland. Uret blev senere mit som julegave, nu en anelse klodset lagt ned i en kapsel, så det kunne fungere som armbåndsur. Det gjorde det så, indtil jeg efter konfirmationen købte mig et »rigtigt« armbåndsur til afløsning af det »russiske«. Disse eksempler nævner jeg naturligvis i dag udelukkende af den grund, at jeg ved, hvad der skete. Hvis jeg var blevet skolelærer, som det jo var min fars drøm, ja, i så fald havde de tre historier ikke haft nogen som helst relevans og var derfor slet ikke blevet husket.

Min far havde dog en betænkelighed ved en seminarieuddannelse. Det var, at jeg - og i det havde han helt ret - ikke havde gehør skabt i livet, og så vidt han vidste, så stillede uddannelsen til lærer dengang krav om, at man kunne spille violin - og hvordan gor man det uden en tone $\mathrm{i}$ livet? Apropos en tone i livet: Kort for studentereksamen kom der pludselig besked om, at vi skulle have karakter i sang. $\mathrm{Og}$ en efter en blev vi kaldt ind i skolens festsal, anbragt ved siden af flyglet og af sanglærer Poul Nielsen spurgt, hvad vi ville synge. Frit valg af eksamensopgave - fint nok. Jeg valgte - uvist af hvilken grund - Grundtvigs salme »Har hånd du lagt på Herrens Plov«. Jeg sang til lærer Nielsens akkompagnement, og da jeg var færdig, bemærkede han, at han aldrig havde hørt noget lignende. Men jeg fik som trøst karakteren "godt + «.

Vi var ankommet med flyttelæsset til det nye sted i Tidsholm den første dag i april 1947. I dobbelt forstand en solskinsdag. Luften var forårsagtig, lidt skarp, men klar, som kun en aprildag kan være. Solen skinnede. Det ville den under alle omstændigheder have gjort i mine forældres hjerter - en gråvejrsdag ville såmænd have været mere end 
nok. Måske var det i realiteten den største dag i deres liv. Større, end da de blev gift, eller da de fik mig. Vores hund, en lille terrier lydende navnet Flink, fejrede dagen ved på eget initiativ at tage et par runder omkring gården. Eller »æ stej«, stedet, som mine forældre ville have udtrykt sig. Også jeg, der kun manglede et par måneder i at fylde 9 år, fornemmede, at der var noget specielt, noget mere end blot forår i luften. Derfor er dagen også blevet stående i min erindring som noget ganske særligt. Vi havde længe set frem til at flytte til det nye sted. Ikke fordi det i størrelse, beliggenhed eller i materiel henseende repræsenterede noget bedre end det, vi havde forladt. Nærmere tværtimod. Hemmeligheden bagved mine forældres forventningsfulde glæde lå gemt $\mathrm{i}$ den ene sætning, som jeg havde hørt dem gentage igen og igen, og som i realiteten rummede alt: - Det er vores eget, her er der ingen, der kan jage os bort. Her kan vi blive så længe, vi selv vil.

Stedet hed og hedder Tidsholm. Tre husmandssteder placeret $\mathrm{i}$ en trekant med det ene husmandssted placeret klos op ad jernbanen, mens de to andre - deraf vores - lå ca. 300 meter nord for banelegemet. Der var et par kilometer til nærmeste stationsby, og vejen dertil var et hjulspor parallelt med jernbanelinjen. Nærmeste by var købstaden Tønder, der lå $8 \mathrm{~km}$ mod vest.

Navnet voldte mig mange kvaler, ikke mindst blandt kammerater og i skolen. Jeg prøvede desperat at udtale det med endog meget blødt "d ", men lige meget hjalp det. Det skærpede formodentlig blot opmærksomheden omkring ordet. - Tisser I meget der?, var en blandt mange morsomheder, som det navn afstedkom. Også en anden ting generede mig tilbagevendende og voldsomt. Det sønderjyske kaffebord er som bekendt omfattende og mangfoldigt, men sommetider kunne det også være repræsenteret med en enkelt komponent. Og det var ikke særlig morsomt for en teenagedreng at høre sin mor med høj og tydelig stemme spørge teenage-kammeraten, om han ikke ville have en knepkage - og senere måske, om han ikke ville have en mere? Spurgt med en mine, der absolut ikke var generet af eventuelle associationer, for min mor kendte helt bestemt ikke ordet $\mathrm{i}$ anden betydning end som bagværk. Det er muligt, den findes i andre udformninger, men min mors knepkage var altså en kvadratisk eller rektangulær småkage med takker i kanterne pga. den kniv, den var skåret ud med. Før den kom i ovnen, blev den smurt ovenpå med æg. Heldigvis var nævnte småkage normalt kun på repertoiret en gang om året - nemlig til jul, men den kan som bekendt også vare til påske. 


\section{Mor og far - marsken og sandet}

Men lad mig forklare baggrunden for mine forældres store glæde hin 1. april 1947. Min far forpagtede sammen med sin bror fra midten af 1920 'erne den statelige stråtækte og firelængede marskgård Bjerremark, der ligger lidt udenfor landsbyen Ubjerg, nogle få kilometer sydøst for Tønder. Hertil kom min mor som husbestyrerinde for de to ungkarlebrødre. I midten af 1990'erne deltog jeg $\mathrm{i}$ en konference om Den russisk-ortodokse Kirke på Bjerremark, nu fredet og omdannet til et fashionabelt og prisbelønnet konferencecenter. Det var lidt underligt at bo i smagfuldt indrettede og komfortable værelser i den nu ombyggede ko- og svinestald - vel vidende, at her havde min far i sin tid malket, fodret og muget ud, mens min mor havde huseret i stuehusets gemakker. Husbestyrerinde-forholdet mellem mine fremtidige forældre udviklede sig til kæresteri, og i 1934 endte det med ægteskab. Jeg siger med vilje ikke »kærlighed«, for dette store ord omgikkes de med stor forsigtighed. Ligesom kys og kærtegn ikke var noget, der var til beskuelse - hverken derhjemme eller i det såkaldt offentlige rum. Og alligevel er jeg ikke et sekund i tvivl om, at de elskede hinanden og følte sig dybt forbundne.

På det tidspunkt, det vil sige i midten af 1930'erne, havde de imidlertid forladt Bjerremark og forpagtet en gård af Kreditanstalt Vogelgesang i Alslevkro, en landsby syv kilometer øst for Løgumkloster, mens min farbror købte en gård i Søvang i nærheden af Øster Højst. Kreditanstalt Vogelgesang var blevet oprettet i 1926 som det tyske bidrag i den dansk-tyske jordkamp, der intensiveredes kraftigt mellem de to verdenskrige. Kreditanstalt Vogelgesang og det danske modstykke Landeværnet skulle med hver deres nationale fortegn opkøbe gårde og sælge dem videre til henholdsvis tyske og danske familier samt yde økonomisk bistand til betrængte landmænd med det formål at hindre gårdene $\mathrm{i}$ at falde $\mathrm{i}$ nationalt »forkerte« hænder. Begge mine forældre tilhørte det tyske mindretal - var altså det, der normalt kaldes hjemmetyskere. Begge havde de som født $i$ henholdsvis 1901 og 1902 kun gået $i$ tysk skole, til dels under 1. Verdenskrigs tumultariske liv. Med Genforeningen var de blevet danske statsborgere, men deres sindelag forblev tysk - formet, som det var af tradition, familie og skole $i$ kejsertidens sensommer.

Men det tyske mindretal i Nordslesvig passede og passer ikke ind i den almindelige definition på et mindretal. Religiøst skilte de luthersk 
reformerte hjemmetyskere sig ikke ud fra det danske flertal. Heller ikke sprogligt - deres dagligsprog var jo ikke tysk, men derimod den danske dialekt sønderjysk, som såvel dansk- som tysksindede respekterede og anvendte som fællessprog. Kun hjemmetyskernes sindelag, dette ubestemmelige begreb, formet af tradition og skolegang, var tysk. Således også med mine forældre.

Det tyske mindretal blev voldsomt inficeret af nazismen. Mange håbede naturligvis på en grænserevision, der atter skulle gøre Kongeån til rigsgrænse mellem Danmark og Tyskland. Forholdsvis mange medlemmer af mindretallet meldte sig til Waffen SS, en stor procentdel meldte sig ind $\mathrm{i}$ den nazistiske mindretalsorganisation NSDAP$\mathrm{N}$ - og langt de fleste mænd meldte sig som Zeitfreiwillige til tysk paramilitær hjemmetjeneste.

Mine forældre meldte sig ikke til nogen af delene. Men jeg husker på trods af min unge alder den dag i dag tydeligt det pres, der blev lagt på dem - og især naturligvis på min far. Diskussionerne i køkkenet var mange og højrøstede, mange forsøgte at overtale ham til at gå med, men han holdt stand. Ikke en gang den tilsyneladende uskyldige fælles suppespisning deltog mine forældre i. I $1945 \mathrm{kom}$ så nedturen for medlemmerne af det tyske mindretal. Maj 1945 var ikke noget befrielsesforår for dem. For mange af dem betød Tysklands totale stats- og civilisationssammenbrud en afsløring af deres åbenlyse svigt $i$ forhold til værtsnationen Danmark. For alle i mindretallet - uanset deres forhold til den nazistiske ideologi - blev befrielsesforårets sammenblanding af naziregimet med den almindelige tyske historie og kultur en personlig og national katastrofe. Der var ikke plads til de finere nuancer - alt tysk lå for had i efterkrigsårene. Das Land der Dichter und Denker blev sammen med nazisternes tolv regeringsår transformeret til Das Land der Richter und Henker. En betydelig del af mindretallet - de påfølgende hurtige losladelser viste for mange - blev i de første ophidsede befrielsesdage interneret i den nu omdøbte Frøslevlejr, Faarhuslejren. Min far klarede frisag - han blev hverken arresteret rigtigt eller ved en fejltagelse af modstandsbevægelsen.

Men et eller andet sted må der i mit sind have været en usikkerhed. Jeg kunne jo huske forkert - jeg var trods alt kun knap 7 år i maj 1945. I hvert fald søgte jeg, da jeg begyndte at tænke på at skrive erindringer, mere konkrete og kontante vidnesbyrd om mine forældres handel og vandel i de fem besættelsesår. Glad blev jeg derfor, da jeg i midten af 1990'erne i Landsarkivet i Aabenraa fandt en skrivelse, som jeg vidste, 


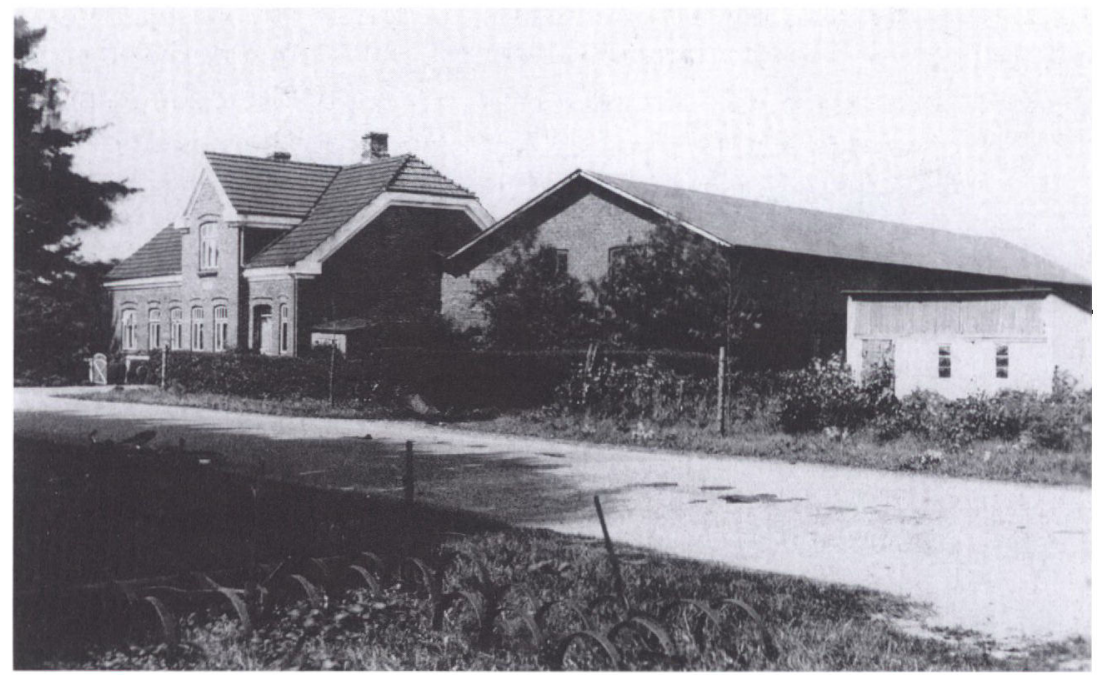

Mit fødehjem i Alslevkro og mit barndomshjem gennem otte år. En ret stor gård, forpagtet af Höfeverwaltungsegesellschaft, en afdeling under Kreditanstalt Vogelgesang. Pa trods af mine forældres korrekte adfærd under Besættelsen måtte de forlade gården til 1. april 1947. Et krav, som i hvert fald min far aldrig forvandt. Landevejen gik fra Logumkloster og til Aabenraa. Over for gården lå andelsmejeriet Arnaa, hois ejer skrev en attest om mine forældres adfard under Besættelsen. Datteren Sigrid blev en af mine legekammerater. Foto i privateje.

måtte findes et sted. Jeg havde hørt mine forældre snakke om den, men havde den overlevet? Men nu stod jeg med originalen i form af en udtalelse, skrevet af vor genbo i Alslevkro, den meget dansksindede mejeribestyrer Søren Petersen. Det fremgår ikke af skrivelsen, i hvilken anledning eller på hvis foranledning den er blevet til, men den er dateret oktober 1946 - altså mens vi endnu boede på gården i Alslevkro. Men jeg gætter på, at det er min far, der har taget initiativet, men den konkrete anledning har jeg ingen anelse om. Jeg gengiver her originalen med dens tekst og tegnsætning:

»Paa given Foranledning kan jeg her udtale at Hrr. Forpagter Annas Petersen baade for under og efter Besættelsen altid har været fuldt korrekt i sin Optræden og ikke nogen tid, saavidt mig bekendt, i mindste maade med sit Sindelag vakt Anstød ej heller udtalt sig nedsæettende om det danske Land og Folk.

Mejeriet Arnaa d. 7/10 1946

Søren Petersen (sign.)« 
Skrivelsen bekræftede altså til fulde den overbevisning, jeg altid havde haft i mit stille sind - at mine forældre under besættelsen naturligvis var forblevet tysksindede, men at de ikke havde gjort noget, der kunne kompromittere dem, eller som kunne anbringes under nazistisk eller anden landsskadelig virksomhed. Det må i sandhed have været en vanskelig balancegang $\mathrm{i}$ betragtning af, hvor inficeret med nazisme det tyske mindretal som helhed havde været såvel før som under besættelsen.

På den baggrund sårede det mine forældre meget, at de alligevel var nødt til at forlade den gård, som de trods alt havde investeret deres kræfter $\mathrm{i}$ og forpagtet $\mathrm{i}$ over 10 år, og hvor de havde svaret enhver sit. I 1945 var det af de allierede blevet bestemt, at al tysk (og japansk) ejendom skulle konfiskeres - altså også i Danmark og her til fordel for den danske stat. Det var der i og for sig ikke noget mærkeligt i på baggrund af Tysklands totale kapitulation. Det, der sårede mine forældre, var tillægsbestemmelserne om, at de tidligere forpagtere - og det tilsyneladende uanset deres adfærd under besættelsen under ingen omstændigheder kunne beholde forpagtningen eller eventuelt købe de berørte ejendomme. Ikke en gang deres privatejede løsøre i form af f.eks. maskiner og husdyr måtte de tage med sig. Det skulle sælges på en meget ydmygende - sådan oplevedes den i hvert fald - offentlig auktion, hvor udbyttet dog tilfaldt mine forældre.

Mine forældre talte helst slet ikke om den uretfærdighed, der fra statens side efter deres mening blev forøvet mod dem som trofaste danske statsborgere, men jeg ved, at det nagede dem - og især min far, der desværre døde allerede i 1962 som en mand, der var slidt op af fysisk arbejde. Min mor, der overlevede ham i 20 år, havde nok nemmere ved at bearbejde og glemme. Men jeg husker en begivenhed, som måske var et plaster på uretfærdighedens åbne sår, og som $i$ hvert fald har tilfredsstillet min fars meget uideologiske, for ikke at sige snusfornuftige indstilling til tilværelsen:

I god tid før den omtalte offentlige auktion, hvor husdyr og løsøre skulle sælges, transporteredes - formodentlig på gåben og ganske ulovligt - i nattens mulm og mørke en halv snes af de bedste malkekøer og to arbejdsheste ned til min farbrors gård i Søvang i nærheden af Øster Højst. Det skulle være vores startkapital på Tidsholm.

I mine forældre mødtes marsken med sandet. Min mor stammede fra Tøndermarsken, dvs. fra den fede og frugtbare inddæmmede havbund omkring Rudbøl, mens min far kom fra de lidet frugtbare sand- 
Et stolt forzldrepar med mig og hunden Valli $i$ midten. Jeg er vel tre eller fire år gammel, så billedet er taget 1941-42. Stoltheden gætter jeg mig til, fordi jeg kom til verden, efter at min mor havde haft flere spontane aborter. Mine forældre havde derfor taget de forste skridt til adoption, da jeg meldte min ankomst. Min mor var den kraftige og hoje af de to, selvom min far med hat næsten kom på omgangshojde. Min mor gjorde flere forsog på at "fede « ham op, fordi hun syntes, han var for mager til alt det tunge stald-og markarbejde - men stort set var hendes anstrengelser omsonst. Foto i privateje.

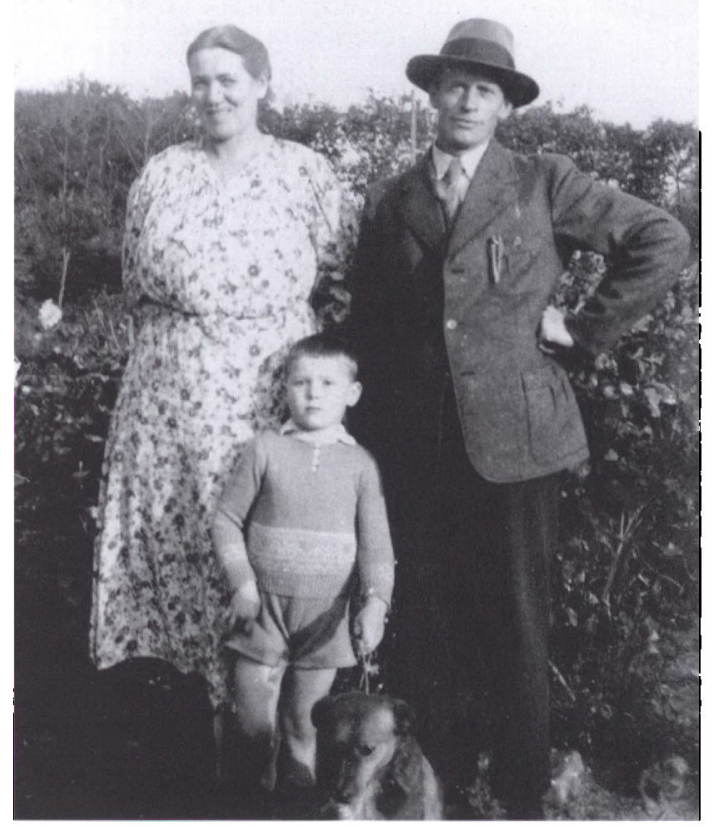

jorde nord for kirkebyen Hostrup. På en måde kan man sige, at han vendte hjem til sandet, da vi flyttede til Tidsholm. Jeg er overbevist om, at deres hjemegns karakteristika kunne aflæses på deres temperamenter, og at jeg har arvet dem i en skønsom blanding. Min mor havde let ved at se tilværelsens lyse sider; hun var lattermild og elskede at være sammen med andre mennesker. Da hun blev alene som kun 59-årig, tog det naturligvis hårdt på hende, og der gik mange år, før hun kom over det. Men hun havde altid familie og venner omkring sig. De kom gerne til en kop kaffe og en snak hos tante Lene, som mange kaldte min mor.

Min far så generelt mere mørkt på tilværelsen - min mor sagde, at han kunne have sine "skroller", hvor han kunne gå stille og indadvendt $\mathrm{i}$ dagevis. Han var heller ikke den type, der tog hurtige beslutninger. Almindeligvis ville han gerne sove på problemet, inden løsningen blev fundet. Men han havde også et stille lune, der bedst kom til udtryk i små historier med en morsom pointe. Generelt sparede han mere på ordene, end min mor gjorde - men når han sagde noget, 
behøvede det ikke at korrigeres eller justeres - eller fortrydes. Tre af mine bedsteforældre har jeg aldrig kendt af den simple grund, at de døde, før jeg fattede noget. Kun min dejlige og varme mormor eller Oma, som hun altid blev kaldt, nåede jeg at kende. Hos hende, der hele sit liv boede Ved Gaden, vejen langs diget mellem Rudbøl og Højer, har jeg været på ferie i mange somre, indtil også hun døde i begyndelsen af 1950'erne.

Min far, Annas Petersen, var født 7. februar 1901 på en stor gård på 150 hektar i landsbyen Solderup et par kilometer nord for kirkebyen Hostrup, hvor han blev døbt og konfirmeret. Han døjede hele livet med sit lidt specielle fornavn, og hans dårlige erfaringer burde være en advarsel til alle nybagte forældre om ikke at udstyre den lille ny verdensborger med et for eksotisk, udsøgt eller fremmedartet navn. De færreste mennesker var så velbevandrede i Biblen, at de vidste, at Annas var den ene af ypperstepræsterne ved Templet $\mathrm{i}$ Jerusalem på Jesu tid - en anden var den mere kendte Kaifas. Utallige var de misforståelser og omskrivninger, det bibelske navn var anledning til.

Jeg har et fotografi - det må være taget i 1904 - og det viser hele familien Petersen stillet op hos fotografen: far, mor og fire børn. Der er for mig noget uendelig tragisk over billedet. Først og fremmest fordi jeg ved, at både min farmor og min faster Pauline, kaldet Line, døde inden for tre år efter, at billedet er taget - begge døde af datidens svøbe, tuberkulose. Min farmor i 1904, kun 36 år gammel, og min faster i 1907, kun 14 år gammel. Jeg mener at kunne se sygdommen lyse ud af deres blege og lidt gustne ansigter. Min farbror Peter faldt som tysk soldat i Nordfrankrig i det strategisk set ligegyldige, men et af alle kriges længste, bitreste og blodigste slag - slaget om Verdun i 1916. Han faldt sammen med millioner af andre unge bondesoldater i 1 . Verdenskrigs skyttegravs-blodbad.

Min far mistede altså sin mor som treårig. Og som seksårig sin fem år ældre storesøster. Med andre ord mistede han med kun tre års mellemrum hele sit kvindelige univers, sin tryghed, sin verden. $\mathrm{Og}$ som femtenårig pubertetsdreng mistede han den ældste af sine store brødre - utvivlsomt et stort tab i en følsom alder. Disse dødsfald var ikke noget, der blev snakket om i mit barndomshjem. De lå naturligvis $\mathrm{i}$ tid hele fire årtier før, jeg fattede noget.

Når jeg overhovedet kender historien, skyldes det forst og fremmest min mor, der i glimt og brudstykker gav mig de fragmenter, der skulle til for blot nødtørftigt at stykke et helhedsbillede sammen. Men også 


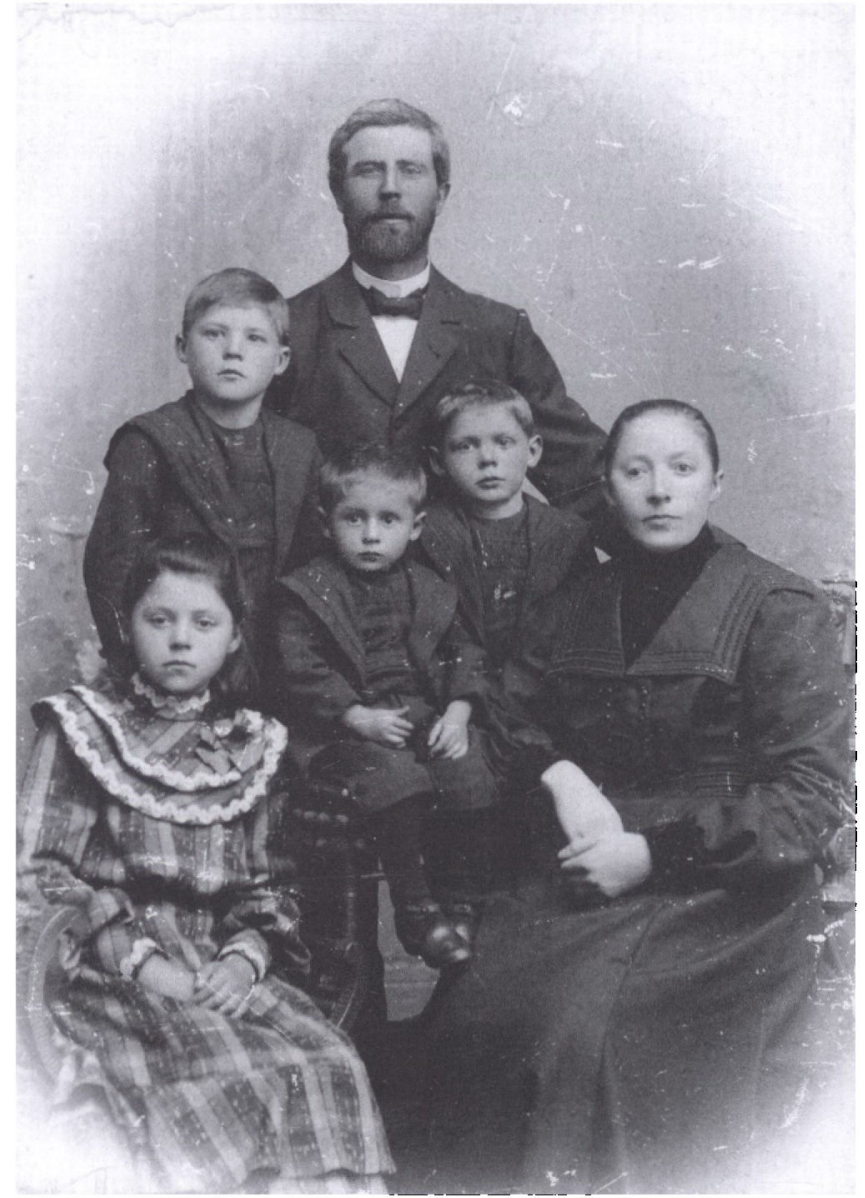

Billedet er taget omkring 1904 - det vil sige kort for min far som fire-årig mistede hele sit kvindelige univers. Moderen døde 1904, da han kun var tre air, og storesøsteren tre air senere - begge af tuberkuløse, datidens svobe. Bagerst står min farfar som patriarken, der beskytter sin familie. Foran står de to ældste sønner, hooraf den ældste, Peter, faldt $i$ 1. Verdenskrig. Mellem dem sidder en på det tidspunkt trearig purk, der skulle blive min far. Nederst i pyramiden eller som familiens basis dens kvindelige element - min farmor og faster. En god borgerlig familie for verden gik af lave i 1914. Foto i privateje.

for hende var det naturligvis kun noget, hun havde hørt fortalt. Min far talte kun nødtvungent om sin barndom. Der var ikke så mange bøger udover Biblen, som min far normalt refererede til. Men Erich Maria Remarques bestseller og antikrigsroman Im Westen nichts Neues fra 1928, hvor forfatteren på baggrund af egne erfaringer beskriver verdenskrig- 
ens grufulde helvede i skyttegravene - den bog kendte min far. Den havde han læst, og den refererede han til en gang imellem med sin storebror in mente. På den måde kunne han ad omveje antyde det personlige tab og den sorg, han som pubertetsdreng havde oplevet ved storebroderens død i 1916. Det var næppe helt tilfældigt, at jeg ved min dåb i 1938 fik min faldne farbrors navn som mellemnavn.

Min mor medbragte ikke sådanne traumer fra sin barndom. Hendes barndomshjem lå Ved Gaden, vejen mellem Rudbøl og Højer. Her blev hun født den 17. juni 1902. Min morfar, som jeg i lighed med min farfar aldrig har kendt, var af profession det mix af arbejdsmand, fisker og landmand, som var så almindeligt omkring Rudbøl sø. Min mormor, Oma, som hun altid blev kaldt, fødte seks børn - fire piger og to drenge. Udover min mor var pigerne Mie, Minna og Anna. Mens drengene hed Mathias og Momme. Bortset fra den ene af drengene, Mathias, som giftede sig med Nikoline på Rømø, og min mor, som giftede sig inde på sandet, boede alle min mors søskende i cykelafstand fra hinanden ude i marsken. Derfor var der altid legekammerater i form af fætre og kusiner i nærheden, når jeg var på ferie hos mormor. Da hun døde, overtog min tante Anne og onkel Julius, der også boede Ved Gaden, værtskabet. Deres tre børn, mine fætre Peter og Hans Christian og kusine Inga, har jeg tilbragt mange pragtfulde sommerferier sammen med.

Deres far, min onkel Julius, havde andel i høslættet i Vadehavet. Når dette spec'elle og meget bløde græs, næret og vandet af saltvandet og utallige mikroorganismer, var slået, skulle det jo ligge og tørre. Derfor skulle det vendes, og det var ofte vi drenges opgave.

Jeg husker disse lange og pragtfulde dage på vaderne, hvor sommervarmen stod dirrende i luften, hvor der var meget højt til himlen, og hvor utallige græssende får og lam sammen med fuglene dannede ramme. Jeg husker også det ualmindeligt bløde og velduftende græs og de medbragte klemmer, pakket ind i kølende rabarberblade. Og jeg husker hjemmelavet saftevand i flasker med patent-kapsel - alt sammen noget, som tante Anne havde forberedt og pakket ned derhjemme. Hvor smagte disse klemmer og denne saftevand himmelsk, og hvor blev vi sultne i den saltholdige luft i det uendelige rum mellem diget, himlen og havet. Når vi skulle hjem, kunne det blive dramatisk. Vi skulle naturligvis have et højt læs hø med hjem. Turen op på diget med læsset og ad den forholdsvis flade vandside kunne gå an, men nedturen på den anden side var stejl, selv om hjulsporet 


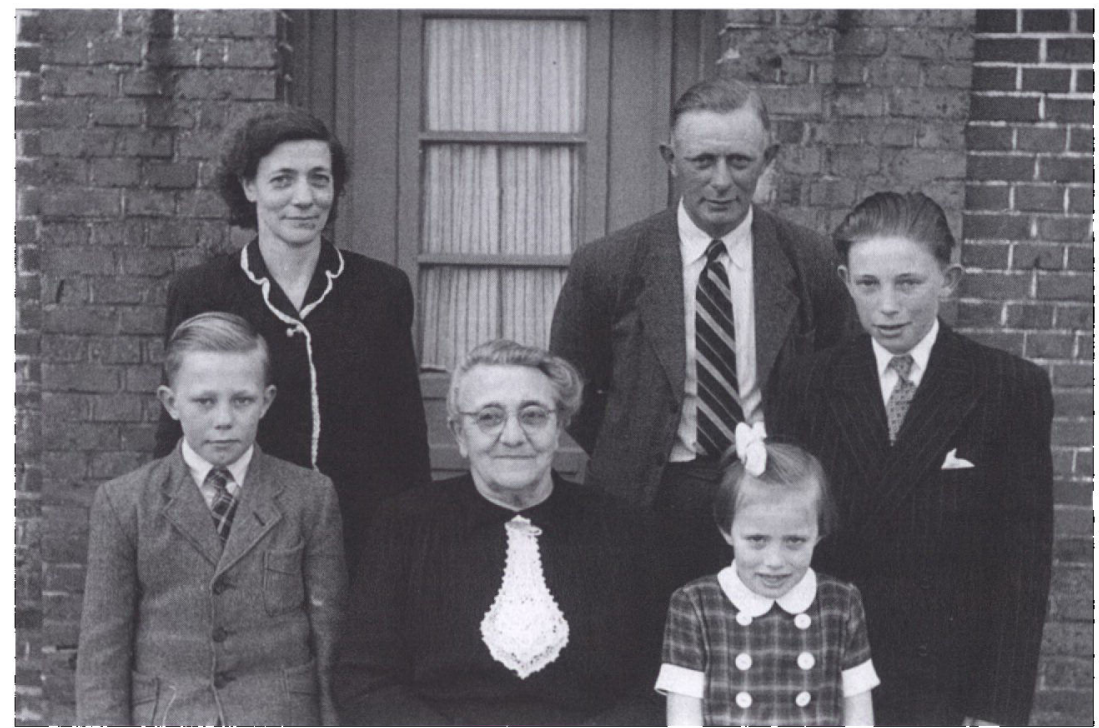

- Har du ikke fået en flad røv af al den læsen? Det var min onkel Julius' omkvæd, når han så mig. Han var ikke så meget for boger. Men jeg har tilbragt mange dejlige sommerferier i min tante Annas og onkel Julius' hjem ved Gaden pả dige-landevejen mellem Rudbol og Hajer. Sammen med mine fxtre Hans Christian og Peter-og med min yngre kusine Inga på sidelinjen. Og centralt $i$ billedet min mormor, min varme Oma, som hun altid blev kaldt. Biledet må være fra omkring $1950 \mathrm{og}$ er taget foran familiens hjem. Foto i privateje.

naturligvis var lagt skråt ned ad diget. Hestene kunne have svært ved at holde vognen tilbage, men som regel kom vi over uden at vælte. Men hvor var jeg bange for, at der skulle ske noget!

Turen fra Tidsholm til Ved Gaden foregik naturligvis på cykel. Strækningen til Tønder kendte jeg udenad fra utallige skoledage. Vestenvinden kunne være strid, men den blev dog af og til opholdt eller drejet af - af huse, bevoksninger eller vejsving. Men når jeg var kommet gennem Tønder og et stykke ud ad vejen mod Rudbøl, kom jeg ned på den lige, flade og lange strækning til Ved Åen. Her var der intet, der opholdt blæsten - den kunne uhindret og i accelererende tempo slå ind $\mathrm{i}$ ansigtet. De næste stykker vej ud til frisergården med den karakteristiske høje rejsning, Vester Anflod, var nemmere. Dels blev vejstykkerne kortere, dels blev modvinden til tider afløst af sidevind. Og endelig det sidste lange stykke vej stik vest og opkørslen til det gamle dige, der udgjorde landevejen mellem Rudbøl og Højer. 
Min mor har fortalt om sin skolegang i Rudbøl. Dens sidste år faldt sammen med 1. Verdenskrig, og hun fortalte, at de sommetider havde flere forskellige enelærere på en uge - af den simple grund, at de blev indkaldt til krigstjeneste. Da hun gik til præst, gik hun på gåben de 6-7 kilometer, der var til kirkebyen Højer. Jeg har indtryk af, at min mors barndom var uden store rystelser, uden alvorlig sygdom og død eller krigsdræbte brødre. Med seks børn har der givet ikke været meget at slå til Søren med i det lille hus bag diget. Men aldrig har hun fortalt om triste eller fattige kår, selv om levevilkårene - også målt med datidens alen - har været begrænsede.

Min mor fik kun mig. Jeg ved, at hun havde haft flere aborter, før jeg meldte min ankomst. Det er nok en del af forklaringen på, at mine forældre pylrede en del om mig, da jeg var lille. To gange i forskolealderen havde jeg lungehindebetændelse-en omstændighed, der bevirkede, at jeg blev belemret med uldne og hjemmestrikkede undertrøjer. Jeg husker, at de kradsede forfærdeligt - lavet som de var af hjemmeavlet og hjemmebehandlet uld. Jeg så med længsel frem til den dag i maj, hvor gøgen lod sig høre første gang. Det var nemlig signalet til, at uldtrøjerne og de lange strikkede strømper endelig kunne lægges i skabet. Lungehindebetændelse $\mathrm{i}$ de tider betød sengeleje $\mathrm{i}$ en rum tid. Jeg husker, at jeg fik blødkogte æg med salt og hjemmebagt franskbrød med smør, năr jeg skulle holde sengen. Det var himmerig.

\section{Langt fra alting}

Vi kom til at bo på Tidsholm i nøjagtigt 10 år - indtil 1. april 1957, med andre ord små tre måneder, før jeg blev student fra Tønder Statsskole, og nøjagtigt tre måneder, før jeg den 2. juli 1957 begyndte som rekrut i Sogårdlejren. Det var ti centrale, vigtige og formative år i min opvækst og udvikling.

Jeg oplevede det nye sted som liggende langt fra alting. I Alslevkro havde jeg haft mange venner og legekammerater, i øvrigt udelukkende piger, i det umiddelbare nabolag. Der var f.eks. de tre Gubi-piger i den nedlagte stationsbygning for enden af en allé og ved den i øvrigt ligeledes nedlagte jernbanestrækning mellem Løgumkloster og Rødekro, og der var den jævnaldrende Sigrid i genbo-mejeriet Arnaa. I øvrigt var det hendes far, der i 1946 havde skrevet ovennævnte "tillidserklæring « om min fars vandel under krigen. I Alslevkro havde jeg som syv eller otte år gammel også oplevet min første store for- 
elskelse - $\mathrm{i}$ hvert fald, som jeg kan huske. Men den var ikke i en af de nævnte piger. Forelskelsen var af en ganske speciel og uvirkelig slags. Jeg havde fået lov til at cykle de syv kilometer til Løgumkloster for at se på det årlige Klostermærken i august måned. Jeg havde fået den sædvanlige enkrone med hjemmefra til at snolde for. I dødsdromen optrådte et par, og jeg havde aldrig oplevet noget lignende. En mand kørte på motorcykel op ad dromens lodrette vægge - det var imponerende. Men mest optaget blev jeg af hans vidunderligt smukke makker. På vejen hjem og mange dage efter fantaserede jeg om den underskønne kvinde. Jeg regnede på, hvor mange års forskel der var på os, og hvornår vi kunne tillade os at blive gift.

Men på Tidsholm var der ingen legekammerater overhovedet på de to andre gårde. De måtte opseges på en afstand af et par kilometer. Men når jeg i mit voksne liv har rejst i udlandet, f.eks. mange steder på landet i Rusland, har jeg gang på gang måttet konstatere, at - lige meget hvor man bor i Danmark - er man egentlig tæt på alting. Men sådan oplevede jeg det ikke dengang. Der var som sagt et par kilometer til nærmeste stationsby og små otte kilometer til nærmeste større by, Tønder. For en otteårs knægt måtte Tidsholm opleves som meget langt ude på landet, og denne opfattelse blev kun styrket af den kendsgerning, at vi hverken havde indlagt el eller telefon. Vi fik telefon i begyndelsen af 1950'erne, mens jeg endnu i foråret 1957 læste lektier og forberedte mig til studentereksamen ved petroleumslamper. De første fem til seks år var vi altså uden direkte forbindelse med omverdenen. Når man betænker, hvordan vi her $\mathrm{i}$ begyndelsen af det 3. årtusind nærmest vælter os i kommunikationsmidler, er det ubegribeligt, at man for blot 50 år siden kunne klare sig med en avis og en batteridreven radio, hvor batteriet altid oplevedes som værende fladt. Hvor ofte har jeg ikke siddet med øret klinet op ad højttaleren for utroligt svagt at høre melodierne i giro 413 søndag mellem $12 \mathrm{og}$ 14. Og i dag med fastnet og trådløs telefon, radio og tv i alle rum, med mobiltelefoner, faste og bærbare computere, betalingsaviser og gratisaviser til overflod. Og så har jeg helt sikkert glemt en hel række af de mange dimser, der står til rådighed for nutidens mennesker.

Sex og seksualundervisning var $\mathrm{i}$ bogstaveligste forstand et fremmedord i 1950'ernes Danmark. Også i Tidsholm og på samtlige de skoler, jeg har gået på. Jeg mindes aldrig at have hørt mine forældre nævne det eller i det hele taget tale om sex eller seksuelle emner. De kendte sikkert slet ikke disse ord eller deres mange afledninger. Jeg 
tvivler også på, om de brugte disse ord indbyrdes eller i det hele taget satte benævnelser på det, der foregik under dynerne. Det er muligt, de har tænkt, at den side af livet fik knægten jo til fulde illustreret ved at iagttage dyrene. Og nægtes skal det da heller ikke, at disse iagttagelser gav en del anskuelsesundervisning. Enten når ornen kom på besøg et par dage og gjorde sin pligt blandt et par lystne søer, eller når den "ysne« ko blev trukket til tyren. Jeg holdt også kaniner, og de gav da også ofte opvisning i deres specielle kunstarter. Men jeg tvivler på, om jeg egentlig i min virkelighedens verden har haft nogen som helst glæde af denne del af dyreverdenen. Måske også gudskelov for det. Mellem kammeraterne blev der naturligvis i smug brugt ord, der refererede til seksuelle emner, men nogen sammenhæng var der naturligvis sjældent $\mathrm{i}$ disse antydninger.

Nej, sex var hverken noget, man talte om i hjemmene, i skolerne eller i det offentlige rum. Det nærmeste, man kom erotiske billeder som teenager, var tilfældige og grumsede tegninger i Boccaccios Decameron og eventuelt de frygtelige billeder af sår på kønsorganerne i kirurgen Fabricius-Møllers bøger om kønslivet. Alt sammen noget, man kunne snige sig til at kigge i efter skoletid, og indtil det næste tog gik - siddende i det bageste og mørkeste hjørne på biblioteket $\mathrm{i}$ Tønder. Også svenske Ivar Lo-Johanssons socialrealistiske og selvbiografiske bøger var pirrende og interessante. Ikke mindst romanen Sommeren med Monica rummede sider, der godt kunne interessere en ung mand med bumser og andre rumsterende pubertetstegn. Mange svenske film havde i 50'erne meget korte, men dejlige og pirrende bade- og nøgenscener - ofte med skærgårdens lys og mystik som kulisse. Derudover kunne det ske, at kiosken havde et blad for nudister om sol og sundhed med et glimt af en hvid mave og resten dækket til. Johannes Allens film Ung leg om nordsjællandske unges vilde lege så jeg, men dens problematik havde ærligt talt meget lidt med min dagligdag at gøre. Og i baggrunden rumsterede norske Agnar Mykles frimodige roman Sangen om den røde rubin, men i gymnasieårene mere i form af referater fra den retssag, bogen blev årsag til, end ved læsning af bogen selv. Ikke underligt, at mange af os hilste den seksuelle revolution og frigørelse velkommen, da den fra midten af 1960'erne endelig kunne vikle sig ud af lovgivningens og traditionens bornerte greb.

Det blev ofte drøftet på Tidsholm, hvad vi, når muligheden forelå, skulle vælge at få indlagt først - el eller telefon. At få lagt el ind var en meget dyr manøvre. Ingen af de tre gårde havde el - det vil sige, 
at der skulle trækkes ledninger over et par kilometer, dertil installationer osv., og alt dette skulle betales efter regning. Telefon derimod var en meget demokratisk indretning - oprettelsesprisen var ens for alle, uanset hvor mange telefonpæle, der skulle rejses, og uanset ledningsnettets længde. Jeg har ofte hørt min mor sige, at skulle hun vælge mellem el og telefon, og selv om det havde kostet det samme at få lagt ind - så ville hun ganske bestemt vælge telefonen. Og det var da også den, vi nåede at få i Tidsholm - formodentlig en gang i begyndelsen af 50'erne.

Denne klare overbevisning hos min mor hang sammen med de galdestensanfald, hun fra tid til anden var plaget af. Sådanne anfald er ualmindeligt smertefulde - jeg kan stadig høre min mors klageråb, når hun lå inde $\mathrm{i}$ sin seng og havde sådan et anfald. I den situation var der kun et, der kunne hjælpe - et skud morfin. I min erindring kom hendes galdestensanfald altid om natten, og så måtte min far af sted på cykel til Jejsing for at ringe efter lægen. Og i 1950'ernes Danmark var lægen altid ens praktiserende læge. Han stod til rådighed døgnet rundt - formodentlig også de fleste weekender.

Så rykkede i de første år doktor Dahl og derefter, da han blev pensioneret, doktor Jark ud fra Tønder, og jeg husker den dag i dag den uendeligt lange ventetid. Jeg er sikker på, at lægen har skyndt sig så meget, han kunne, men jeg drog forst et lettelsens suk, når jeg på lang afstand gennem vinduet kunne se de længe ventede billygter. For at illustrere 1950'ernes lægeservice kan jeg nævne, at doktor Jark en nat kom i en forrygende snestorm - efter at min far i det samme vejr på cykel havde stridt sig frem til telefonen. Da Jark ikke kunne forcere snedriverne længere, tog han skiene frem fra bagagerummet og bragte på dem den med længsel ventede morfin. Så faldt min mor til ro, det gjorde vi andre også, og lægen kunne drage af igen. I min mors sind var der derfor ingen tvivl - telefonen havde første prioritet, på trods af de numerisk langt flere glæder og lettelser, elektrificeringen kunne have bragt med sig. Først mange år efter - $\mathrm{i}$ foråret 1963 - tog min mor sig sammen til at lade sig operere, men hun blev det alligevel aldrig. Mens hun var indlagt på Tønder Sygehus med henblik på operation, blev min far pludselig syg med en hjerneblødning. $\mathrm{Nu}$ havde jeg, som enebarn og boende i Århus, med et slag begge mine forældre liggende på sygehuset. Fjorten dage efter at han var blevet indlagt, døde min far - uden at være kommet til bevidsthed efter sit slagtilfælde - og kun 61 år gammel. Det var naturligvis en frygtelig 
og sørgelig situation for os alle sammen, men trods alt nok mest for min mor. Det tog hende det meste af en halv snes år at komme nogenlunde over tabet af min far - den mand, som hun havde boet og arbejdet sammen med $\mathrm{i}$ tredive år.

Lad mig tilføje - også jeg havde overordentlig stor glæde af telefonen. Pludselig kunne jeg kommunikere med mine kammerater vedrørende lektier og andre ting, men timelange samtaler blev det aldrig til - af den simple grund, at det ligesom lå i luften, at telefonen kun var opfundet til korte beskeder. Den kostede efter forbrug og var absolut ikke egnet til pjat. Når jeg den dag i dag er en elendig telefonsnakker, hænger det ganske givet sammen med denne omstændighed.

\section{Jorden, dyrene og arbejdet}

Bortset fra et par tønder engjord var det meste af de 30 tønder jord, der hørte til vores gård, sandjord - med tryk på sand. Den var naturligvis nem at arbejde med, og der var ikke problemer med marker, der efter voldsomme regnskyl stod under vand. Hovedproblemet var ofte i højere grad mangel på vand - især om foråret, når korn og roer skulle vokse og i det hele taget komme godt i gang. Og så i begyndelsen af sommeren, når kornet skulle sætte kerner. Jeg kan huske år, hvor der efter forårssåningen fulgte en forårsstorm med tilhørende sandflugt og med det resultat, at det meste af sæden ved vindens kraft endte $i$ den ene ende af marken. Hele såningen kunne altså begynde forfra. Jorden var naturligvis lige så følsom over for tørkeperioder. Den dag i dag kan jeg for mit indre blik se min far stå ude på gårdspladsen en majdag, spejdende efter bare en lille sky, der var villig til at afgive noget væde til de tørstende korn- og roemarker. Høsten var afgørende for gårdens økonomi. En dårlig høst betød uvægerligt større regninger hos mølleren og grovvarefirmaet - for så var man nødt til at købe ekstra foder til dyrene om vinteren. Og disse regninger betød igen et stort indhug i næste års høstudbytte. Det vil sige, at familien på den måde kunne komme ind i en ond cirkel, som det kunne blive endog meget svært at komme ud af.

Sprøjtning mod ukrudt kendte vi faktisk ikke. Jeg husker det $\mathbf{i}$ hvert fald ikke. Det betød naturligvis ikke, at der ikke fandtes ukrudt på markerne. Men jeg er overbevist om, at datidens intensive behandling af markerne var et effektivt middel mod ukrudtet. Roehakkeren, 
der række for række sommetider var i gang to eller tre gange i løbet af en sæson, kom jo næsten manuelt i berøring med hver eneste plante samtidig med at alt ukrudt blev fjernet ved hver hakning. Jeg har hakket mange roer, men jeg var mildest talt ikke vild med dette arbejde. Jeg syntes, rækkerne var uendeligt lange, og solen bagte som regel fra en skyfri himmel. Senegræs var et stort og tilbagevendende problem på den sandede jord. Det blev om foråret efter pløjningen harvet sammen i store bunker og brændt af. Alligevel dukkede det trofast op igen det følgende forår - enhver haveejer kender problemet. Det er umuligt at få bugt med.

Høsten var naturligt årets største begivenhed på et lille brug. Det var den, der afgjorde familiens økonomi for det følgende år. Det var også den, der afgjorde, hvor stor købmandsregningen og gælden til mølleren skulle blive $\mathrm{i}$ årets løb. Ganske vist betød varme og væde også en del i vækstperioden. Men uanset hvordan forår og forsommer vejrmæssigt havde været, var det trods alt høstperioden og dens vejr og vind, der i sidste ende afgjorde, hvordan afgrøden kom i hus. Når tiden nærmede sig, gik min far jævnligt og tyggede på kernerne i aksene. Han hævdede på den måde at kunne afgøre, om kornet var tjenligt til at blive høstet. Men jeg kan ikke huske, at vi nogensinde har arbejdet på en søndag - uanset, hvordan vejr og kornets tjenlighed flaskede sig. Det var min fars klare overbevisning, at det, man havde tjent om søndagen, mistede man om mandagen. »Kom helligdagen $\mathrm{i}$ hu, "var et mantra i mit barndomshjem. En indstilling, som min far helt sikkert bragte med sig fra sit meget religiøse barndomshjem.

Når kernerne havde bestået lakmusprøven mellem min fars tænder, gik høsten ind. Først skulle der slås en kant rundt om hele marken. Ellers ville hestenes hove og selvbinderens hjul ødelægge kornet. Det foregik således, at vi med leen høstede et skår og bandt det op i neg med hånden. I hjørnerne var det nødvendigt at lave lidt mere plads. Så var det selvbinderens tur. Neg efter neg sprøjtede den ud kadencen afhang naturligvis af, hvordan kornet havde stået. Ofte måtte selvbinderen stoppes, fordi bindegarnet var gået $i$ stykker ikke mindst i de krigs- og efterkrigsår, hvor det var lavet af snoet papir. Når selvbinderen var færdig, og negene lå spredt ud over marken, skulle de sættes i skok. Seks til otte neg blev stillet skråt ind mod hinanden, for at de kunne tørre. Før mejetærskeren var det ikke almindeligt, at kornet blev tørret kunstigt efter høsten. Det foregik på 
marken - en proces, der selvfølgelig i allerhøjeste grad også afhang af vejret. Stod skokkene for længe på marken i skiftende regn og sol, risikerede man, at kernerne begyndte at spire - og så var kornet stort set ødelagt. Når negene var tørre og tjenlige, skulle de køres hjem. Det krævede to mand. En, der med en fork langede negene op på kassevognen, og en, der lagde dem i en sådan orden, at der kunne være flest mulige neg på læsset. Blev det for højt, eller var negene ikke lagt ordentlig, risikerede læsset at vælte under hjemkørslen. Så blev læsset kørt hjem og ind i laden, hvor negene nu blev forket op på loftet og stakket der. Her lå de så, indtil det skulle tærskes.

Jeg husker tiden mellem høst og tærskning som en lidt problematisk tid. Hvis kornet ikke havde været tørt nok, når det blev kørt ind, risikerede man, at det begyndte at bræmme. Det vil sige, at man risikerede, at der gik ild i kornet ved selvantænding. Ildebrand var naturligvis altid et skrækscenarium på en stråtækt gård. Især min mor gav udtryk for denne frygt. Og min far havde i denne forbindelse ikke de samme hårdtslående argumenter, som han havde overfor frygten for lynnedslag - nemlig ved at henvise til lynaflederne. I forbindelse med kornet havde han kun den meget subjektivt bestemte forsikring om kornets tørhedsgrad at ty til. Det blev aldrig til ildebrand i min barndom, men den var hver eftersommer en truende mulighed.

Indtil et par måneder lå høsten i laden og på loftet i Tidsholm. I hvert fald indtil det tidspunkt, hvor det traktortrukne tærskeværk under stort spektakel rullede ind på gårdspladsen. Det var en stor og begivenhedsrig dag i min bevidsthed. Bare monstrummet i sig selv. Men også den hektiske aktivitet og den fremmede arbejdskraft, der skulle hjælpe til. Min mor havde travlt i køkkenet-situationen og mændene krævede kraftig og ikke mindst rigelig mad. Tærskeværket blev stillet op og klargjort i ladens gennemkørsel, traktoren anbragt, så den via en trækrem kunne levere den nødvendige energi. Og tærskningen kunne begynde. Negene tog endnu en gang turen på forken, men denne gang den ultimative tur ned til manden, der tog imod dem, skar snoren over og lænsede neget med aksene vendt nedad ned i værket. En ansvarsfuld post, for han skulle både sørge for, at tærskeværket ikke fik for meget at arbejde med ad gangen, og samtidig passe på ikke selv at ryge med ned i det uhyggelige og kværnende hul.

Men resultatet var godt nok. I den ene ende løb det tærskede korn i stride strømme ned $\mathrm{i}$ de til formålet anbragte jutesække - en tønde = $100 \mathrm{~kg}$ i hver. Normalt en post, min far vogtede, så sækkene ikke løb 
Min far ved stalddoren mod vest på Tidsholm. Her lå også moddingen, og til højre var dasset anbragt. Det er mig, der har taget biledet. Min far ind tager en for ham meget karakteristisk positur med den ene arm $i$ siden. Lige inden for doren var hestebåsen, adskilt fra den øvrige stald og med plads til vore to arbejdsheste Lotte og Max. Resten af stalden husede grisesøer, slagterisvin til opfedning, malkekøer og eot. ungkiæg. Foto i privateje.

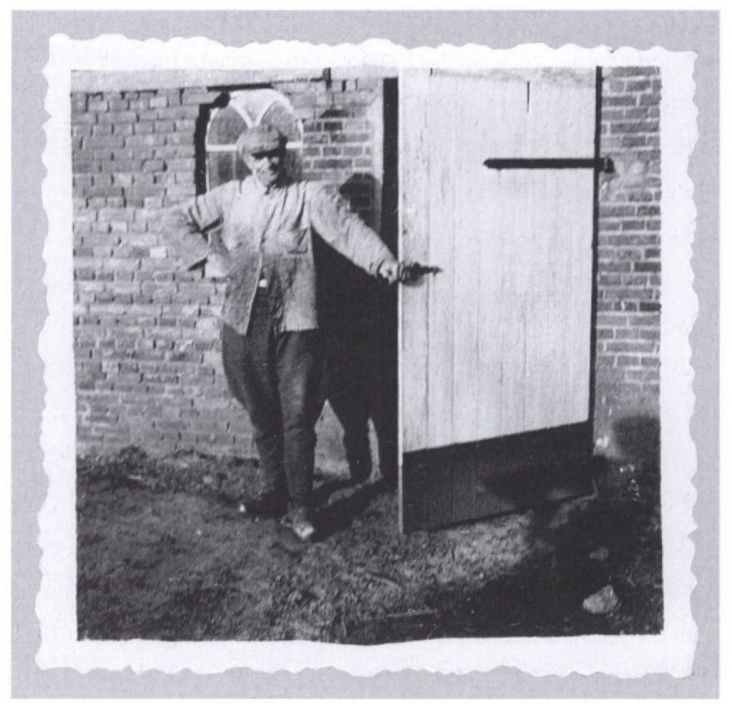

over. I den anden ende kom halmen ud, bundet i nydelige baller, kaldet klapninger. Da jeg blev stor nok, fik jeg normalt den opgave at sørge for, at de blev fjernet. For at de så bagefter kunne blive læsset op på loftet - som vinterens foder og strøelse. Når dagen var omme, tærskningen overstået og ligeså min mors frygt for ildebrand i endnu et år, drog tærskemanden atter af sted til næste opgave. En lang, hektisk og begivenhedsrig dag var til ende.

Forbavsende, hvor mange arbejdsgange, der skulle til for at udfylde den funktion, som mejetærskeren med et snuptag kan varetage. Den fandtes i 1950'erne, men var ikke særlig udbredt. Der fandtes maskinstationer, der høstede for folk. Min far så på dette nymodens instrument med mistro og skepsis. Kornet var ikke tørt, når det blev høstet på roden med mejetærsker - var han overbevist om. Sandt var det, at det ofte efter høsten med mejetærsker skulle tørres med ekstraudgifter til følge. Min far forholdt sig i det hele taget dybt skeptisk til de nye maskiner. De var alt for tunge og bevirkede sammen med traktoren, at jorden blev presset unaturligt sammen. Jeg skal ikke gøre mig klog på, om der var noget om snakken. Der er ingen tvivl om, at min far var overbevist om sine teoriers holdbarhed. Men jeg har ham en lille smule mistænkt for at have ligget under for den samme tankegang, som ræven var offer for med de sure rønnebær. 
Med sølle 30 tønder jord og med den dyrkningsform, mine forældre valgte på Tidsholm, var der simpelthen ikke penge til overs til en gennemgribende modernisering.

Udover tærskedagen var der en gang mere om året, hvor der var fremmed arbejdskraft på gården - men nu af en yngre kaliber. Det var, når kartoflerne skulle tages op om efteråret. Vi havde som regel en lille hektar sat til med kartofler. Så det var mange kartofler, der skulle tages op. Den sandede jord var som skabt til kartoffelavl. Det var sorten bintje, der næsten havde monopolstatus som spisekartoffel i de år - den er stadig gængs, men er nu i konkurrence med mange andre. Vi har også haft den rødnistrede sort King Edward med den faste struktur og gode smag, men den gik for at være meget vanskelig og sart at dyrke.

I princippet burde kartoffelhøsten jo falde i kartoffelferien - i moderne terminologi: efterårsferien. Men af en eller anden grund passede den ikke altid ind i systemet. På den berammede dag mødte en flok - af en eller anden grund altid drenge - op efter skoletid. Nogle havde tidligere bragt sig på den sorte liste hos min far - formodentlig fordi de mere havde brugt de kostbare kartofler som kasteskyts mod hinanden end som noget, der skulle puttes ned i de specielle kartoffelkurve, forsynet med to hanke. Min far stod for opgravningen. En hestetrukken maskine slyngede kartoflerne cirka en meter ud til siden, hvorefter vi »daglejere" fulgte efter og samlede dem op. Processen kunne godt strække sig over et par dage. Og derefter drog den ungdommelige arbejdsstyrke videre til næste kartoffelavler. Lønnen kunne variere - den korte høstperiode kunne påvirke udbud og efterspørgsel. Nogle arbejdsgivere var mere gavmilde end andre. Saftevand og anden forplejning kunne ligeledes variere i såvel mængde som kvalitet og eventuelt bruges som lokkemiddel overfor den labile arbejdskraft. Lønnen kunne svinge mellem seks og syv, måske helt op til otte kroner pr. eftermiddag. Det samlede beløb kunne godt snige sig op på en halvtredser for en sæson, når man havde været hele rækken af arbejdsudbydere igennem.

Den sidste aktivitet i marken før efterårspløjningen var roeoptagningen. Sædvanligvis i oktober måned, men den foregik i flere tempi. Som regel havde vi turnips som en tidlig foderplante. Den blev normalt hevet op ved håndkraft med stængel og rod og kørt hjem i daglige portioner. Ofte blev den smidt til køerne på marken som et supplement, når græsset hen på efteråret blev mere sparsomt. Dens lave indhold af tørstof og tilsvarende store vandindhold samt dens beskedne krav til jordbundens beskaffenhed gjorde netop turnips til et typisk tilskuds- 
foder. Men dens skarpe lugt og smag kunne give en kedelig afsmag i mælken. Basisroen var imidlertid kålroen, som vi imidlertid altid kaldte kålrabi. Det var den, der skulle holde vinteren over og sammen med hø og halm udgøre det grundlæggende foder for malkekvæget. I stuvet form fik vi den også sommetider serveret på middagsbordet. Kålrabi har jeg også spist i rå form, når sulten meldte sig udenfor spisetiderne. Roehøsten foregik i flere tempi. Den begyndte med, at kålrabien blev aftoppet med et specielt jern, der kunne minde om et skuffejern. Men i daglige portioner, der ligesom turnips var et foder-supplement, mens køerne endnu var på græs. De aftoppede roer blev taget op med en roeoptager, der samtidig med optagningen skar roden af. Hver roe blev dernæst med håndkraft og en spids greb forket op i kassevognen og kørt hjem i roekulen, hvor de atter med en roegreb blev læsset af. Roekulen skulle længst muligt holdes åben - ellers kunne roerne rådne i et mildt efterår. Men når frosten nærmede sig, kunne der lægges et lag halm over roerne som en første beskyttelse. Når vinteren så rigtig satte ind, blev der yderligere kastet et lag jord ovenpå halmen - og roerne var beskyttet. I løbet af vinteren kørte vi så roer til et par dages forbrug med trillebør ind $\mathrm{i}$ loen, hvor de blev raspet ved håndkraft og "serveret« for køerne. Ligesom tilfældet var med det enkelte neg, passerede den enkelte roe gennem mange faser, før den nåede sit endelige bestemmelsessted - tærskeværket eller koens mave.

\section{Økonomi på vågeblus}

Økonomien på et lille husmandssted var altid følsom. Selv små rystelser i dagligdagen trak lange skygger efter sig. En ko, der viste sig alligevel ikke at være med kalv og derfor ikke gav mælk. En so, der ligeledes viste sig at være gold. Eller som lå grisene ihjel, eller en anden, som fik få eller måske dødfødte grise. Et husdyr, der døde måske på trods af dyre dyrlægebesøg. En malkeko, der pludselig blev trepattet. Tilsyneladende små episoder, men alligevel altid alvorlige sociale begivenheder på en lille bedrift, hvor pengeøkonomien $\mathrm{i}$ forvejen var beskeden og stram, mens terminer, købmands- og foderstofregninger skulle betales til tiden og med rede penge. Hestene var normalt forsikret, men det var produktionsdyrene ikke. Jeg husker tidspunkter, hvor mine forældre siddende sammen i køkkenet desperat diskuterede eller ledte efter løsninger på en eller anden betalingsfrist - hvad enten løsningen så blev $\mathrm{i}$ form af en kortfristet og i almin- 
delighed forhadt veksel eller måske en ydmygende anmodning om udsættelse med betalingen. Jeg kan også huske tidspunkter, hvor de ganske vist med udtrykt væmmelse - delte en bajersk øl og røg en cigaret, fordi de havde hørt, at det kunne dulme nerverne. Nydelsesmidler, som de ellers aldrig rørte. Bajersk øl kunne til nød opvarmet bruges som medicin mod en stærk forkølelse - og cigaretten eller cigaren havde min far naturligvis fået tilbudt et eller andet sted - som regel nok i banken. Noget, der var gratis, skulle man naturligvis aldrig sige nej tak til. Det kunne altid bruges som tilbud til en gæst.

På et tidspunkt blev jeg sælger, og det hang sådan sammen: Min far var hele tiden optaget af at finde på nye aktiviteter, der kunne kaste lidt ekstra penge af sig. Vi havde et ualmindeligt sandet stykke jord, som lå klos op ad et levende hegn - det syntes som skabt til dyrkning af hvide asparges. Dybe render blev gravet, fyldt op med god staldgødning, og oven på det blev aspargesplanten med det karakteristiske buskede rodnet spredt ud. De første år måtte man ikke høste, planterne skulle samle kræfter. Men så gik det ellers løs - de hvide, sprøde og ualmindelig velsmagende asparges må kun lige bryde jorden, før de stikkes (= høstes) med en specialkniv. Ellers når de at blive grønne. Det blev stort set min mors opgave at tage sig af denne afgrøde, men jeg har også hjulpet til. Tidligt op, det vil sige omkring kl. 4, når solen stod op. Høsten strakte sig fra begyndelsen af juni til Skt. Hans - så der var tale om tre hektiske uger. Afsætningen blev min opgave. Den foregik i begyndelsen ved, at jeg gik eller cyklede fra hus til hus i Tønder og tilbød bundter med friske asparges. Efterspørgslen var stor, så forretningen gik godt. Efterhånden fik jeg faste kunder - og så blev forretningen udvidet. Vi kunne jo også tilbyde slagtehøns og æg. Efter to år blev de æglæggende høns slagtet og kunne så sælges som unge suppehøns. Slagtningen var en stor proces i sig selv. Hønsene skulle have hovedet kappet af, blodet skulle løbe af dem, og de skulle skoldes i gruekedlen, derefter plukkes og til sidst holdes over en spritflamme, der tog de sidste fine dun. De finere fjer og dunene kunne bruges i dyner og puder. Og mine asparges-kunder var flittige aftagere af de plukkede, men ikke rengjorte høns. Så vidt jeg husker, krævede myndighederne, at man ikke fjernede indvoldene, det vil sige ikke »blev taget ud«, og at ben og fødder blev siddende på kræet. Ordet salmonella var endnu ikke opfundet udenfor laboratorierne, og ordet fugleinfluenza eksisterede ikke.

Disse sideaktiviteter bidrog naturligvis til basisbedriften med sup- 
plerende indtægter. Men ovenstående er naturligvis udtryk for, hvordan jeg som dreng oplevede situationen dengang: At økonomien ofte var på vågeblus. Men set i bakspejlet må jeg konstatere, at vi i sagens natur aldrig sultede og egentlig havde det godt - maden var jo lige for hånden og som regel i rigelige mængder. Vi oplevede heller ikke pludselig arbejdsløshed, som mennesker i byerhverv konstant havde som en reel trussel. Det glemte min far som regel, når han gav udtryk for, hvor nemt, det hele var, når man vidste, at hver den første i måneden var der en fast lon til rådighed. Derimod hang tvangsauktionen og frygten for at skulle forlade gården altid som en truende og frygtelig mulighed for en landmand. Og især, når der altid var huller, der skulle fyldes ud med de sparsomme kontanter.

Mine forældre talte ofte om 1930'erne, som de havde oplevet på egen krop, og hvor risikoen for netop tvangsauktionen som følge af de lave landbrugspriser var stor og ofte også en realitet. At skulle forlade gården, fordi man ikke kunne svare enhver sit, var og er det ultimative nederlag for enhver landmand. Mine forældre kunne også fortælle om forfærdelige tilfælde, hvor spilledjævelen havde fået gårdejeren til i kortspil at miste eller pantsætte hus og hjem hen over hovedet på kone og børn. Måske derfor fandtes der ikke et rigtigt spil kort i mit hjem. Eselspil, ludo, mølle og halma kunne gå an. Men kortspil var sammen med spritten djævelens værk, som man skulle holde sig langt fra. Så jeg mindes ikke, at vi har haft hverken et spil kort eller en flaske snaps i mit hjem. Måske også en arv fra min fars missionske hjem. Skak spillede han imidlertid gerne. Han lærte mig dette pragtfulde, men også uhyre tålmodighedskrævende spil, men hans interesse for spillet kølnedes en kende fra det tidspunkt, hvor jeg begyndte at vinde for ofte.

Den stramme økonomi medførte også, at der blev passet på, når en so skulle fare, eller en ko skulle kælve. Så sad min far oppe om natten, mens jeg efter bedste evne afløste ham nogle timer, så han kunne få sovet bare lidt. Det var vigtigt, at grisene straks efter fødslen blev taget fra soen og puttet ned $i$ en kasse med halm, så de kunne holde varmen. Men også for at undgå, at soen af vanvare eller af fødselsnervøsitet trådte på grisene eller lagde sig på dem. Moderne varmekasser var en umulighed - alene af den grund, at vi ikke havde el. Det var også vigtigt, at f.eks. slim straks efter faringen blev fjernet fra grisenes tryne. Ellers kunne de blive kvalt. Og når så fødslen var overstået, skulle grisene lægges til moderen og fordeles ved de enkelte patter. Det kunne også ske i sjældne tilfælde, at en so fik så mange grise - i sig selv jo en 
glædelig ting - at hun ikke havde patter nok. Der var et utal af små gøremål i en stald, der ikke var udstyret med moderne faciliteter.

Jeg kan huske en faring, som resulterede i en helt usædvanlig situation, som heldigvis var uhyre sjælden. Et par dage efter fødslen opdagede min far en morgen, da han kom ud i stalden, at alle de nyfødte grise var svulmet op på en underlig måde. Ved nærmere eftersyn viste det sig, at de alle - og der var en halv snes stykker $i$ alt - var født uden endetarmsåbning. Gode råd var dyre. Dyrlæge ville en landmand altid helst undgå - $i$ hans øjne var en sådan studeret mand altid dyr at lukke ind i stalden. Og min far var ingen undtagelse. Når man kunne fjerne mælketænder på nyfødte grise og kastrere dem, kunne man vel også selv tage affære i en sådan situation. Så min far tog resolut et barberblad og skar forsigtigt et hul der, hvor det rettelig burde være. Det viste sig, at tarmen sad helt, som den skulle, og "operationen « resulterede synligt, lugtmæssigt og hørligt øjeblikkeligt $i$ en umådelig lettelse for grisene. Nogle enkelte af dem døde af kvaksalveriet, men jeg kan huske, at langt de fleste overlevede og kunne sælges ganske normalt otte uger senere.

Vi solgte som regel grisene i otte-ugers alderen. Enkelte fedede vi selv op og solgte som slagterisvin, når de havde nået den fastsatte slagtevægt. En enkelt gris beholdt vi til hjemmeslagtning. Det var englænderne, der dikterede priserne og i det hele taget alt for mange ting, mente i hvert fald min far - der skulle jo tages hensyn til deres højt elskede morgenmad med dansk bacon. I det hele taget var min far ikke ligefrem begejstret for deres prispolitik. Hovedsynspunktet var, at de englændere ikke ville betale nok for danske landbrugsvarer, og at Danmark var alt for afhængigt af og tjenstvilligt overfor deres ønsker og krav. Mens de nok skulle bestemme, hvad de ville have for deres kul og andre varer.

Når min far handlede smågrise, skete det under iagttagelse af et nøje - ganske vist uudtalt og aldrig nedskrevet - ritual og sæt af regler. I god tid inden grisehandlerens ankomst havde grisene fået en særlig stor portion frisk og stridt rughalm at boltre sig i. Halmen bevirkede, at de hurtigt blev rene og lyserøde, så de grangiveligt lignede marcipangrise. Min far stod inde i grisestien og præsenterede den skrigende vare ved at tage den $i$ bagbenene og op $i$ favnen - den skulle selvfølgelig sælges for den størst mulige pris. Grisehandleren stod ude i midtergangen - han havde pengene, men ville naturligt nok gerne have varen så billigt som muligt. Det var markedsøkonomi 
i sin mest primitive form. Mellem dem foregik et sælsomt spil med klare psykologiske overtoner - et spil, jeg som iagttager kun kunne få en fornemmelse af. Hvis man koblede lyden fra, kunne spillet godt minde om fugles parringsdans. Ved hjælp af fagter, tilsyneladende håndslag, småudbrud, ofte af brummende karakter, vredesudbrud, ledsaget af et kropssprog, der lod ane, at modparten da simpelthen ikke var rigtig klog - ved hjælp af alle disse virkemidler søgte de at nå frem til en handel, begge parter kunne være tilfreds med.

Gang på gang var min far hovedrystende på vej bort fra stien, et par minutter senere var det så grisehandlerens tur til at nærme sig udgangen. For så et øjeblik senere at vende tilbage, tage min fars åbne håndflade og med et klask slynge et nyt tal ud og med en forsikring om, at det var hans absolut sidste bud. Så tog min far grisehandlerens ligeledes åbne håndflade, klaskede den og udstødte et andet tal ligeledes med en forsikring om, at det var hans sidste bud. Hvilken trylleformel, der fik begge parter til at vende tilbage, forblev en dyb hemmelighed - gemt i psykologiens krinkelkroge. Eller også skyldtes det blot, at begge parter var oprigtigt interesseret $i$ en handel. Som oftest nåede de to kombattanter til enighed om en pris - men sommetider skulle de helt ud på gårdspladsen, for det endelige håndslag var en kendsgerning. Min fars og grisehandlerens kendskab til hinanden stammede naturligvis kun fra optrinnene i stalden. Deres baggrund var vidt forskellig, og deres krav og forventninger til tilværelsen ligeledes helt forskelligartede. Alligevel lignede de set udefra og i den konkrete handelssituation to mænd, der kendte hinanden godt. De havde i den givne sammenhæng et fælles, ofte tavst sprog, de havde et fælles adfærdsmønster og sidst, men ikke mindst havde de naturligvis et fælles mål med deres komsammen.

Jeg nævnte, at et enkelt slagterisvin om året blev reserveret til hjemmeslagtning. Slagtedagen var en travl dag. Uden adgang til elektricitet og dermed kølefaciliteter skulle slagteprocessen helst afsluttes samme dag. På den aftalte dag kom den professionelle hjemmeslagter med sine remedier. Grisen blev ført ud i gården under skrig og skrål, slagteren tog sin forhammer og slog den for panden. Grisen faldt om på siden med benene strittende i ryk. Så var slagteren klar med den store slagterkniv, som han stak $\mathrm{i}$ halspulsåren. Blodet pulsede ud, mens min far holdt en spand under for at opfange det. Derefter skulle der røres rundt i blodet, så det ikke koagulerede. Imens blev grisen smidt op i et trug med kogende vand, der i forvejen var varmet op i 
gruekedlen. De nu løse børster blev skrabet af grisen, der derefter, renvasket, hvid og marcipanagtig, blev lagt op på en stige, spændt fast og stillet op ad huset med hovedet nedad. Slagteren skar den op fra ende til anden, og de endnu dampende indvolde væltede ud. Hjerte, lever, tarme og nyrer blev skilt ud.

Derefter kunne slagteren begynde en grovpartering af grisekroppen, hvorefter min mor overtog processen med at finpartere i skinker, bove, brystflæsk, grisetæer, flæskestege, koteletter, hakkekød osv. Hovedet blev kogt med henblik på at lave sylte. Kød blev hakket for at lave medisterpølse og spegepølser i grisens nu rensede og steriliserede tarme. Jeg kan huske, at vi i mange år saltede store mængder grisekød ned - en konserveringsmetode, der var almindelig, indtil frysehusene fra begyndelsen af 1950'erne blev almindelige. Vi lejede en frostboks i det andelsejede frysehus i Jejsing. Det vil sige, at hver gang der skulle hentes noget $\mathbf{i}$ fryseren, var det frem med cyklen og afsted. Men metoden var naturligvis et enormt fremskridt i forhold til de traditionelle opbevaringsmuligheder. Selv om min far - som landmand og dermed en naturligt konservativt indstillet person - var sikker på, at kødet nok mistede noget i smag ved den nymodens stil at fryse det ned.

\section{Dasset, petroleumslampen og Giro 413}

Moderne mennesker med stål- og granitbelagte samtalekøkkener har svært ved at forestille sig et præmoderne køkken. Hvor alt vand skulle slæbes ind fra pumpen på gårdspladsen og ligeledes fragtes ud $\mathrm{i}$ en spand efter brug. Hvor der med andre ord hverken var afløb eller kloak. Hvor der skulle slæbes brændsel ind til komfuret og kakkelovne, og hvor de hver morgen skulle renses for aske og slagger. Og hvor alt til madlavningen skulle hentes i et spisekammer beliggende $i$ husets mest kølige krog. Alligevel husker jeg med glæde livet omkring komfuret og dets varme. Eller for eksempel de søndag morgener, hvor der var bagt frisk franskbrød, og hvor det sammen med smør og honning blev til guddommelige mundfulde. Men jeg husker også de vintermorgener med klingende frost og snedriver op til de isblomst-dekorerede vinduer. Hvor vi klemte os sammen, tæt op ad den kamin, der kun langsomt spredte lidt varme i den iskolde stue. Men det betød jo ikke, at de andre rum som soveværelse, entre og køkken automatisk blev varmet op. Her var der bidende koldt. Måske derfor, at jeg altid - vinter som sommer - har sovet med åbent vindue. 
Toiletforholdene var uhyre primitive på sådan en lille gård. Træk-ogslip var naturligvis udelukket - simpelthen af den grund, at der ikke var indlagt vand eller afløb. Dasset eller lokummet, som vel var en mere dækkende betegnelse, var ikke placeret inde $i$ huset, men derimod i et lille skur, klistret til muren - $\mathrm{i} ø v$ rigt til samme side, som møddingen lå. Et bræt i en meters bredde og med et hul i midten, dækket af et låg med håndtag, var de synlige herligheder. Neden under hullet var der en spand med hank. Var spanden fuld, og det syntes jeg, den var alt for ofte, fjernede man brættet $\mathrm{g}$ bar spanden ud på møddingen. Ved siden af hullet lå en stabel gamle Jydske Tidende, som man kunne læse eller genlæse under forestillingen, inden de endte (!) som toiletpapir. Så jeg er nok ofte kommet $i$ skole med gamle nyheder bagi. Om vinteren var det en ret kold forestilling - så på den årstid var avislæsningen noget mere sporadisk. Lokummet brugtes nok mest af min mor og mig. Min far foretrak at sidde bag køerne - måske lidt forskudt, for ikke at komme i karambolage med kreaturer med samme ærinde. Her var der trods alt varmen fra dyrene at hygge sig med, og så kunne det daglige udbytte også samlet køres på møddingen på trillebøren. Det var naturligvis en uhyre pinlig ting at have kammerater med hjem og skulle præsentere dem for denne oldnordiske indretning, når de blev trængende. Men det var vilkårene.

Vaskeforholdene var naturligvis lige så primitive. Renligheden var formodentlig generelt underprioriteret $\mathrm{i}$ de år, når man sammenligner med vore dages wellness-badeværelser. Afvaskningen foregik i form af etagevask med det vand, der i forvejen var hentet ind fra den manuelt betjente pumpe på gårdspladsen - og måske varmet op til husbehov. Til forskel fra mine forældre havde jeg naturligvis den store fordel i hvert fald et par gange om ugen at kunne komme i brusebad efter gymnastik. I detaljer, hvordan mine forældre fik sig holdt rene, ved jeg faktisk ikke - jeg har i hvert fald ingen erindring om at have vidst det. Om sommeren og $\mathrm{i}$ det hele taget, når vejr og temperatur var til det, plejede jeg at stille mig i en balje ude på gårdspladsen og så skylle mig med en spand vand over hovedet.

Lyskilden $i$ alle stuehusets rum var petroleumslamper - enten hængende ned fra loftet eller i form af standerlamper, der kunne flyttes rundt. I stalden anvendtes en flagermuslygte. Hvis petroleumslamper ikke holdes i pinlig stand blandt andet ved, at vægerne regelmæssigt klippes til - så oser de, og der lægger sig et lag af sod overalt. Dertil skulle disse petroleumslamper af messing med mellemrum pudses. 
Det var også et problem, efterhånden som sådanne lamper blev en sjældenhed, at skaffe lampeglas, dvs. de glasrør med forskellig diameter, der sættes ned omkring flammen, og som bevirker, at den får en rolig og stabil brænding, og at den overhovedet kan give lys fra sig. Der var ikke lamper i alle rum, så derfor skulle man have en lampe med, hvis man skulle hente noget, og der var mørkt udenfor.

I det hele taget tænker jeg tit, hvor mørkt der egentlig var ude på landet. Ganske vist havde jeg jo som regel en dynamolygte på cyklen, men den gav jo ingen lys, når man holdt stille. En gang var jeg rigtig bange. Det var en mørk vinteraften. Jeg havde været $\mathrm{i}$ »Kino« $\mathrm{i}$ Tønder og set en film, der hed Dr. Mabuses testamente - en rigtig uhyggelig og hårrejsende film. Den var et gysende uhyggeligt portræt af en forbryder, Dr. Mabuse, der ved hjælp af blandt andet hypnose og psykologisk fjernstyring forsøgte at styre sine kumpaner til at erobre verdensherredømmet. Jeg husker endnu doktoren i slutsekvensen sidde med vanvittige og opspilede øjne, med et stort hvidt og tjavset og til alle sider strittende hår, mens han desperat forsøger at få orden på sine mange papirer, der flyver til alle sider. Jeg har senere erfaret, at bemeldte film, der er lavet i 1932 af den kendte instruktør Fritz Lang, og som skulle have haft premiere i marts 1933, altså to måneder efter nazisternes magtovertagelse, blev forbudt, fordi den fortolkedes som en kommentar til Tysklands politiske udvikling. Men hvor var jeg bange den mørke aften, da jeg cyklede de otte kilometer hjem til Tidsholm. Jeg husker det som var det i går. Aldrig havde jeg oplevet den kendte cykeltur så lang og så uhyggelig.

Men jeg husker også frostklingende aftener, hvor fuldmånen lyste, hvor stjernehimlen foldede sig ud i hele sin enorme og brogede udstrækning, og hvor man næsten kastede skygge i månelyset. Så kunne jeg føle mig i pagt med naturen i en grad, som man meget sjældent oplever i en moderne verden, hvor der er så mange kunstige lyskilder. I sådanne situationer fik man anskuelsesundervisning $\mathrm{i}$, hvorfor ældre tiders mennesker følte sig som dele af en større sammenhæng, og hvorfor myter opstod og florerede.

Vore stuer var meget lavloftede og med synlige træbjælker. Efterhånden som jeg voksede til og blev over en meter og halvfems høj, kunne jeg ikke gå under bjælkerne uden at bøje hovedet. Men når man et par gange har banket hovedet ind i sådan et massivt stykke bjælketræ, lærer man forbavsende hurtigt at bukke hovedet i rette tid. På samme måde lærte man at klare sig, når akkumulatoren - en 


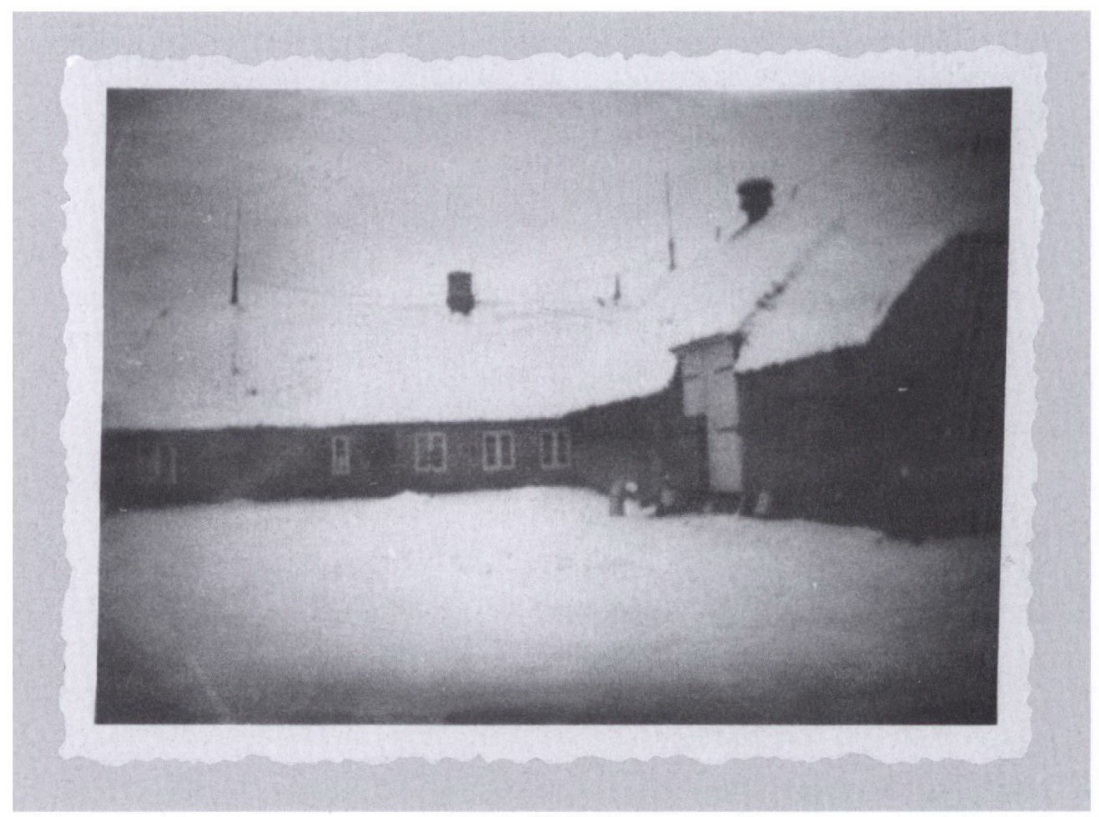

Et kig ind $i$ gården på Tidsholm $i$ vintervejr. To længer - med stuehus $i$ den ene og stald og lade $i$ den anden. Udenfor hoveddøren vandpumpe og brond. På tagrygningen skorsten og aftræk fra stalden og så de omstridte lynafledere, der altid var til diskussion, når naturen lynede og bragede. Min mor mente, siddende med fingrene i orerne og kufferten pakket, at min far tog tordenvejret alt for nonchalant. Mens han henviste til lynaflederne, der naturligvis altid lige var efterset. Jeg stod midt imellem, usikker - men dog med pilen visende mod min far. Jeg har taget billedet med mit eget apparat. Foto i privateje.

enorm glasboks med flydende væske og to elektroder - gav så lidt strøm, at man skulle have øret helt hen til højttaleren for at høre giro 413. Undtagen de søndage, hvor Kino i Tønder spillede en Tarzanfilm. Så stod man i kø i en times tid, før billetsalget åbnede - billetterne var naturligvis unummererede, så det gjaldt om at få en god plads. Et par timer i selskab med junglens hersker, hans pige Jane og chimpansen Cheeta var tilstrækkelige til at nære fantasiens billeder $i$ en grad, så de absolut måtte realiseres derhjemme. Udrustet med tømmen og andre reb klatrede jeg op i træerne og brugte dem som lianer samtidig med, at jeg efter bedste evne efterlignede de hyl, der havde lydt i biografens mørke. Tidsholm og stedets omgivelser var for en stund omdannet til Afrikas jungle, selv om et par af dens centrale personer unægteligt manglede.

På et tidspunkt blev jeg mælkemand, men en lidt usædvanlig af 
slagsen. De tre gårde, der udgjorde Tidsholm, skiftedes i princippet jeg mener at kunne huske en uge ad gangen - om på hestevogn hver morgen efter malkningen at bringe mælken til mejeriet i Jejsing. Men af en eller anden grund, som jeg ikke kan huske, blev de tre bondemænd en gang i begyndelsen af 1950'erne uvenner. Med det resultat, at der hver morgen nu kunne iagttages tre ekvipager, der alle styrede mod deres fælles mål og med hver deres 2-3 mælkejunger på vognen. Naturligvis en fuldstændig latterlig situation, men når sønderjyder bliver stædige, er omkostningerne åbenbart uden betydning. Værre var det, at jeg på en måde blev offer for stædigheden. Jeg cyklede jo alligevel hver morgen til Jejsing for derfra at tage toget til Tønder, og om eftermiddagen vendte jeg hjem ad samme rute. Så en skønne dag præsenterede min far mig for en Longjohn. Ingen af os kendte den gang køretøjets rette navn, det var formodentlig noget, der kun blev brugt blandt svajere i København. For min far og mig var der tale om en cykel med et lille hjul $i$ front og med et lad mellem forhjul og styr, hvor der lige var plads til tre mælkejunger. På den måde blev jeg i en periode mælkemand - indtil temperamenterne atter faldt til ro. Om morgenen bragte jeg de tre junger til mejeriet, parkerede dyret og tog toget 7.15 til Tønder. Om eftermiddagen gentog turen sig - nu blot den modsatte vej. Og med tre junger futmælk eller valle på ladet. Det var betegnelsen for den væske, der blev til rest efter processen med henholdsvis at kærne smør eller lave ost. I tørt vejr og i klingende frost var køretøjet forholdsvist let at manøvrere, men i silende regnvejr og i de perioder, hvor frosten blev afløst af tøvejr, sank det lille forhjul og såmænd også det større baghjul ned i hjulsporets søle og gjorde det vanskeligt at træde dyret frem.

Men en skønne dag gik uoverensstemmelsen over, og normale naborelationer kunne genetableres. Og jeg kunne slippe for mælkekørslen. Bedst havde vi det med de naboer, der boede nærmest - det vil sige kun et par hundrede meter borte. Vore jorder stødte op til hinanden, og da vi fik telefon, var det helt naturligt, at de efter behov kom over for at låne den. Naboen, familien Johannes Mathiesen, bestod af et ægtepar noget ældre end mine forældre - og en ugift søn, Andreas, kaldet Dres, der boede hjemme. Det var meningen, at han skulle overtage gården, når han stiftede familie, og så skulle forældrene bo der på aftægt. Dres havde som så mange andre sønderjyder tæt på grænsen fundet ud af, at piger var i overskud på den anden side af den dansk-tyske grænse som en følge af verdenskrigens voldsomme mandefald. Så også Dres 
valgte den nemme måde at skaffe sig en kone på. Efterhånden blev det påfaldende - der var jo heller ikke så meget andet at holde øje med - at Dres næsten hver aften, når han var færdig i stalden og med dagens øvrige dont, steg på cyklen, renvasket og kæmmet.

Jeg fattede efterhånden, hvad der foregik - han skulle selvfølgelig »til bruds«, som det hed, når der var tale om stævnemøder. Han cyklede en snes kilometer syd for grænsen og hjem igen om aftenen - for han skulle jo op og passe bedriften næste morgen. Men anstrengelserne bar frugt - han hjembragte en brud, Christine, de blev gift, og et års tid senere fik de tvillinger - en dreng og en pige. Jeg fortæller det, fordi disse to børn, fra de kunne gå, meget tit kom spadserende hånd $i$ hånd over til mine forældre. Og de nød i fulde drag igen at have småbørn omkring sig. Da vi senere flyttede til Tønder, og jeg var flyttet hjemmefra, besøgte de mine forældre, og det fortsatte også efter, at min far døde i 1963. Min mor satte stor pris på deres besøg, der fortsatte lige, indtil hun døde i 1983. Da jeg senest besøgte Tidsholm en gang i 1990'erne, var der indrettet golfbane på familien Mathiesens jord, mens »vores« gård og jord så meget forsømt ud. Tønder kommune havde allerede 1990 købt Andreas Mathiesens 30 ha. På det tidspunkt havde Tønder Golfklub anlagt en golfbane på de 15 ha., men i dag disponerer den over hele 57 ha, så jeg går ud fra, at den også har overtaget »vores « jord. Mathiesens gård er indrettet som klubhus.

\section{Jorden og troen}

Jeg kan huske en lille episode, som på udmærket vis illustrerer min fars forhold til sand. I første halvdel af 1950'erne dukkede ord som turisme, feriegæster og sommerhuse oftere og oftere op i den offentlige debat. Min far havde i avisen set, at der på Rømø, der i 1948 var blevet forbundet med fastlandet med en dæmning, var et sommerhus til salg. Måske kunne der her ligge en givtig kilde til ekstraindtægter gennem udlejning til dette helt nye massefænomen - turister. Min far drog på en heldagstur til Rømø - hvordan kan jeg ikke huske, men sandsynligvis med rutebil. Derimod kan jeg tydeligt huske hans tilbagekomst. Begejstringen kunne efter hans ansigtsudtryk at dømme ligge på et meget lille sted. Jo, han havde da besigtiget huset og grunden. Men han havde ikke købt sommerhus - huset var måske med sine to små rum og beliggende helt ude i yderste klitrække til at leve med. Men grunden, det var jo bare det rene hvide sand - mange 
gange værre end det, han var vant til, og det var såmænd slemt nok. Det kunne ingen anstændig landmand da give penge for? Et standpunkt, som måske ikke lyste af den store fremsynethed, men som siger meget om bønders, og ikke mindst min fars tænkemåde. Vi fik aldrig noget sommerhus, og problemet var efter min bedste hukommelse heller aldrig til yderligere debat.

Min fars forhold til sand havde helt sikkert også indflydelse på hans forhold til religion. Sammenhængen mellem jordbonitet og religionens beskaffenhed er jo en for længst fastslået kendsgerning. Min far var vokset op i et meget bibeltro og missionsk hjem, og han tog meget af missionen med derfra. Min mor havde et betydeligt mere afslappet forhold til kristendommen og religion i det hele taget. Hvis jeg havde spurgt hende - men det gjorde jeg naturligvis aldrig - om hun var troende, ville hun i klare vendinger have afvist mit spørgsmål med, at det var hun selvfølgelig. Mine forældre gik regelmæssigt i kirke - på cykel og i det fine tøj. Men alligevel var der stor forskel på mine forældres tro. Hvis min mor havde kendt ordet, ville hun have kaldt sin for grundtvigsk. Livet skulle leves her og nu, selvfølgelig var der en højere mening med det, og lige så selvfølgeligt var der noget efter døden, men det behøvede man ikke gå så højt op i.

Min far, derimod, kunne få anfægtelser - ikke mindst når der var et eller andet i dagligdagen, der gik skævt. Hvad mon han så havde gjort forkert og i strid med Guds love? Et dyr, der døde, en dårlig høst, sygdom - hvem kunne sige, om det ikke var et tegn? Havde han gjort eller forsømt noget, som en højere magt nu gjorde opmærksom på gennem en form for straf? Der blev naturligvis aldrig sat ord på - for mange ord var altid mistænkelige. Men jeg kunne mærke det i småting, som jeg ikke er i stand til at beskrive. Min far blev indadvendt $\mathrm{i}$ de situationer, sagde kun det allernødvendigste og var i det hele taget vanskelig at greje. Situationen gjorde mig utryg og usikker - også fordi den naturligt nok på en eller måde også implicerede min mor. Hvis jeg nogensinde har savnet søskende til at dele usikkerheden med, så var det i disse tilfælde. Men det endte naturligvis altid med, at vi vendte tilbage til normale forhold. Min mor kunne tydeligvis heller ikke lide situationen. Hun kunne finde på at skælde min far ud, og som regel fremmede det normaliseringsprocessen. Hendes i princippet lyse sind krævede en rensning af luften.

Mine forældre gik som sagt regelmæssigt i kirke. Utrygge økonomiske situationer bevirkede fra tid til anden, at min far også søgte de 
missionske kredse. Min mor fulgte med til bønnemøderne - men uden at vise nogen større fornøjelse ved det. Hvor ofte har jeg ikke hørt hende betvivle troen i de meget frommes selvtilfredshed. $\mathrm{Og}$ at deres gerninger ikke altid svarede til, hvad de prædikede. Når det kom til stykket, gav hun ikke meget for deres fromhed i praksis. Møderne foregik hos købmand Lorenzen i Jejsing, hvor vi handlede, og da jeg gik i skole og var venner med to af familiens sønner, Holger og Kjeld, var det ganske naturligt, at jeg fulgte med, uden at vi drenge naturligvis deltog i selve mødet. Det foregik oven på købmandsforretningen, og jeg kan endnu huske de mere eller mindre uartikulerede lyde, som afvekslende med tale og sang kom fra mødelokalet. Det eneste forsonende ved seancen for os drenge var, at vi fik serveret sodavand sammen med den obligate chokoladekage.

Når jeg skriver om min fars forhold til Missionen med et stænk af ironi og afstandtagen, er det egentlig helt uretfærdigt. Den var en del af min fars opdragelse, og hans slidsomme og flittige liv uden nogen form for luksus eller overflod gav ham egentlig ikke nogen anledning til at lægge afstand til den. Når jeg alligevel tillader mig at ironisere en smule over det missionske, skyldes det naturligvis, at skolegang og uddannelse gav mig det privilegium at se tilværelsen i et lidt bredere lys. Og jeg kan kun være mine forældre taknemmelig for at have givet mig den mulighed. Sidst men ikke mindst vil jeg i den forbindelse slå fast med syvtommersøm, at de aldrig har prøvet på at presse mig til at få bestemte holdninger - heller ikke religiøse. Naturligvis lærte jeg at bede aftenbøn, og før måltidet bad min far bordbøn. Det var en ganske naturlig ting i det miljø, der var min barndoms. Mine forældre gav mig i det hele taget nogle byggesten og nogle basale byggeregler. Men opførelsen af huset overlod de til mig at realisere. Og jeg kan med overbevisning sige, at jeg aldrig fra deres side eksplicit har hørt bebrejdelser over den vej og de meninger, som jeg valgte. Hvad min far i sit stille sind har tænkt om det liv, der fulgte med studier og studenterliv i det for ham fjerne og ukendte Århus, tog han med sig i graven. Men jeg føler mig overbevist om, at han under alle omstændigheder ville have været stolt af sin eneste søn, hvis han havde fået lov til at følge mit liv.

\section{Ny viden og nye horisonter}

Jeg havde set dem ligge i vinduet nogle dage. Hos boghandler Jefsen i Tønder, og der var bogudsalg. Fire tykke bind i stort format. De havde 

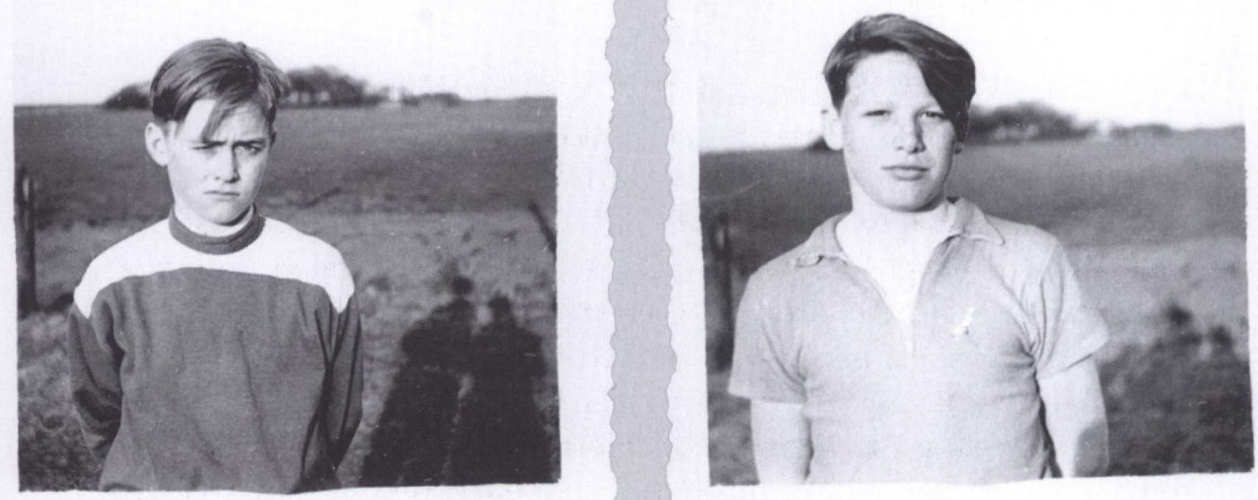

Min gode kammerat gennem såvel mellemskolen på Tønder Kommuneskole som gymnasiet på Tønder Statsskole, Kjeld (Dall Petersen), og jeg har her fotograferet hinanden med mit nyerhvervede kasse-fotografiapparat. Stedet er Tidsholm en gang $i$ begyndelsen af 1950 'erne. Oven i købet er vore skygger kommet med på billedet. Fotos i privateje.

ligget der i dagevis og virket dragende på mig. Det drejede sig om Gyldendals Verdenshistorie, og jeg har været omkring 16 år - på tærsklen til gymnasiet. Titlen virkede som en magnet på mig. At tænke sig: hele verdens historie i fire tykke bøger. Jeg havde fattet interesse for historiefaget $\mathrm{i}$ løbet af mellemskolen. Hjemme lavede jeg på forhåndenværende papirstykker oversigter over valdemarernes historie og tiden efter dem. Jeg havde pengene til bøgerne, der kostede $40 \mathrm{kr}$. Ikke på lommen, men de fremgik af det regnskab, som jeg førte over mit tilgodehavende for udført arbejde i mark og stald. Halvtreds øre i timen var taksten, og i sirlige rækker stod dato og det daglige antal timer opført i et lille hæfte. Min far rykkede ikke ud med pengene til bestemte forfaldstidspunkter, men på anfordring kunne jeg få udbetalt det beløb, jeg skulle bruge. Og nu var det altså hele 40 kroner - lønnen for firs timers arbejde. Det var en stor dag, da jeg troppede op hos Jefsen i Storegade og bad om at købe det store værk i vinduet.

Og det var en stolt køber, der forlod boghandelen med pakken under armen. Selvfølgelig havde jeg enkelte bøger derhjemme. Men det var børnebøger, som jeg havde fået som gave til fødselsdag eller jul. Undervejs hjem med bogpakken på bagagebæreren var jeg flere gange stærkt fristet til at stoppe og bare kigge i nyerhvervelsen. Til sidst kunne jeg ikke nære mig - ned på grøftekanten og pakke op. Bøgerne var hæftet og skulle først sprættes op. Men ved at skille et par sider med fingeren lykkedes det at læse lidt, men resten måtte 
vente, til jeg kom hjem og fik fat $i$ en kniv. Og så gik det stærkt med at få sprættet de tykke bøger op. Mange år senere bragte jeg de fire hæftede bind til Th. Lauersens bogtrykkeri for at få dem indbundet $\mathrm{i}$ halvlæder. Jeg har dem stadigvæk - har ikke nænnet at smide dem ud, selv om deres værdi som verdenshistorie for længst er falmet og overhalet af nye tolkninger - og på trods af, at de ofte har været i vejen.

På et tidspunkt i begyndelsen af 1950'erne blev min verden rystet af en stor nyhed - der skulle køre lyntog på »vores« jernbanestrækning. Jernbanens og togets kultur- og erhvervshistorie er dragende, fascinerende og rig på facetter. Tænk blot på et tog, trukket af et rigtigt damplokomotiv, der prustende og stønnende på en frostklar dag er på vej ind på en station. Damp og røg går op i en højere enhed, iskrystaller glimter i luften, mens forventningsfulde passagerer på perronen og bag de endnu lukkede togdøre gør sig klar til at stige af, stige på eller blot at modtage nogle længe ventede gæster. Åbningssekvensen i den folkeelskede Danmarkskrønike Matador er et godt eksempel. Ofte bliver jernbanens historie som kultur- og samlivsrevolutionerende faktor imidlertid overset. Dens samfundsøkonomiske betydning er ofte blevet registreret og beskrevet - den kunne jo udtrykkes i tørre tal. Men dens kulturhistoriske betydning - jernbanens indflydelse på de bløde værdier, på menneskers liv og samliv, på tankens ubændige higen og flugt - er kun erkendt i sporadiske glimt.

Jeg hører allerede læserens indvendinger: Spiller toget ikke en betydelig rolle i litteraturen? Spiller det ikke en hovedrolle som længselsobjekt for Herman Bangs forsømte kvindelige hovedperson i mesterværket Ved vejen? Er jernbanen ikke det element, som den verdensberømte forfatter Lev Tolstoj gør til handlingens forbindende led og til titelpersonens skæbne i sin vidunderlige kærligheds- og skæbneroman Anna Karenina? Indvendingerne er mange og helt legitime. De kan ikke afvises - lige så lidt som den rolle, jernbanerne har spillet $\mathrm{i}$ by- og egnsudvikling. Hundreder af stationsbyer skød op langs deres spor i Danmark, Europa og i den globale omverden - nogle på den bare mark, andre som sideskud på eksisterende byer og landsbyer. Og stationsbyerne ligger der stadig - ganske vist ofte forsømte eller sat på vågeblus af en udvikling, der prioriterede hastighed og store byer højere end udvikling af nærmiljøer.

Mindre kendt og påagtet er imidlertid togets og jernbanens rolle som kulturfaktor og billedskaber i netop nærmiljøet og i en tid, hvor 
charterrejser og andre flimmeroplevelser endnu lå gemt $\mathrm{i}$ en tåget fremtid. Nemlig i tiden før 1960 for de titusinder af anonyme iagttagere, for hvem toget bare var noget, der kørte forbi. Noget, der i disse iagttagere rejste det horisontudvidende spørgsmål: Hvor kommer det fra, og hvor skal det hen? Den rolle spillede toget i min barndom. Rejser var noget, jeg ind imellem kunne læse om i Jydske Tidende - de indgik ikke i mit nærmiljø eller i min hverdag. Og hvis de forekom, var det højst i form af korte endags-skoleudflugter til Okseøerne i Flensborg Fjord, Munkebjerg ved Middelfart eller Fanø.

Med jævne mellemrum luntede et par motorvogne forbi Tidsholm ad den enkeltsporede strækning. For en dreng i de tidlige teenageår spillede strækningen og de par vogne, der gjorde den levende, en dobbeltrolle. De var et konkret transportmiddel, der kunne bringe mig de syv kilometer til byen, når årstid, vejrlig og opblødte veje gjorde cyklen mindre tjenlig. Togets anden rolle var langt mindre konkret - den var spændende, dragende og bevidsthedsudvidende. Købstaden Tønder var endestationen, selv om byen også havde forbindelse nordpå mod Bramming og sydpå over landegrænsen til Niebüll. Men i mit verdensbillede var marskens hovedstad endestationen, målet. Derfor lå det ukendte og dragende forst og fremmest mod øst. Hvor kørte toget hen efter at have sat mig af på min endestation, Jejsing? Jeg vidste naturligvis, at det på en eller anden måde havde forbindelse til hovedstaden. Men hvordan, hvor ofte og hvor lang tid var naturligvis spørgsmål, der flittigt optog min fantasi om togets rolle ud over min konkrete lille verden.

Pludselig blev alle mine barnlige fantasier imidlertid konkrete og nærværende. Det forlød nemlig, at DSB havde besluttet endelig at berige grænselandet med en direkte forbindelse uden skift i Tinglev og Fredericia til København - oven i købet uden skift til og fra færge i Nyborg og Korsør. Størstedelen af Jylland havde for længst fået lyntogsforbindelse til hovedstaden - det var sket i forbindelse med den forste Lillebæltsbros indvielse i 1935. Og nu 15 år senere skulle Sønderjylland som den sidste landsdel have eget lyntog, Sønderjyden, et af de røde. Det genvundne land havde lige siden Genforeningen med rette følt sig forsømt. Blandt embedsmænd var det kun genforeningsberusede idealister, fantaster eller personer, der af den ene eller den anden grund havde gjort sig udtilbens $i$ "det gamle land ", som søgte eller blev sendt til Sønderjylland. Det var i hvert fald min mors faste overbevisning, og noget var der nok om snakken. 
Det nye røde lyntog skulle udgå fra henholdsvis Sønderborg og Tønder, kobles sammen i Tinglev og derefter uden skift befordre passagerne til kongens København. Selv på Storebælt kunne man blive siddende $\mathrm{i}$ toget, forlød det $\mathrm{i}$ mere indviede kredse. Skinnerne var ført over på færgen. Det var meddelelser, der kunne sætte fantasien i sving. Pludselig blev strækningen øst for Jejsing ændret fra et »no mans land «, fra et ukendt frontier-område til noget håndgribeligt til noget, jeg måtte forholde mig til.

Nyheden om lyntoget satte en masse tanker i gang. Bare betegnelsen »lyntog « fremkaldte billeder, der var i slægt med naturfænomener. Lyn havde vi respekt for på en afsidesliggende gård med stråtag.

Hvad så med et lyntog? Ville man overhovedet være i stand til at opfatte det med det blotte øje, når det fór forbi? Hvor skulle man overhovedet placere sine øjne, når man ville gøre sig håb om blot at opfatte et glimt? Det var blot nogle af de spørgsmål, der meldte sig $i$ hovedet på den 12-årige i månederne for den store begivenhed. Det gjaldt naturligvis om at være udhvilet og godt forberedt. De bedste betingelser skulle skabes, når man skulle konfronteres med det ukendte. Og den store, længe ventede dag oprandt endelig - passagen var planlagt til at finde sted 8.15, men det gjaldt om at være i god tid.

Skuffelsen var imidlertid enorm og næsten ikke til at bære. I stedet for et rødt ildsprudlende uhyre, der med lynets fart bevægede sig gennem rummet, så jeg to skidenbrune motorvogne komme luntende som om, de havde alt for god tid og ikke var på hastig vej til rigets hovedstad. Med andre ord det samme ensformige syn, som jeg havde set hver eneste morgen. Hvad var egentlig forskellen? Den naturlige konklusion var naturligvis at give min mor ret: Sønderjyderne kunne ikke forvente sig noget godt, når nye initiativer kom fra »æ gammel land «.

Erindringen om min barndoms lyntog er kommet tilbage til mig, når jeg en menneskealder senere befandt mig i det store udland. Som for eksempel den gang i Irkutsk i det østlige Sibirien, hvor jeg fra et hotelværelse på den anden side af floden Angara kunne iagttage tog efter tog, det ene længere end det andet, passere forbi på Den transsibiriske Jernbane. Jeg vidste med min forstand, hvor de skulle hen, og hvor de kom fra - men deres billedskabende rolle var den samme, som jeg havde oplevet i min barndom. Eller den gang midt i det europæiske Ruslands kærneland, hvor vi i bil pludselig blev stoppet af en bom, der gik ned. Efter en rum tid gik bommen atter op, men det bemærkelsesværdige var, at der ikke var passeret noget tog. Min 
skuffelse over min barndoms lyntog, der endelig dukkede op, havde været mindre, såfremt det aldrig var dukket op.

\section{Skolerne}

Min skolegang havde jeg påbegyndt, mens vi endnu boede i Alslevkro. Men jeg var kommet sent i skole. Jeg fyldte 7 år i befrielsessommeren, men som følge af de uafklarede skoleforhold kom jeg ikke i skole til april 1945, som var tidspunktet for skolestart på landet. Alle tyske skoler og kulturinstitutioner blev lukket - ganske givet med god grund, fordi de var blevet gjort til spydspidser $\mathrm{i}$ den nazistiske ideologi og propaganda, kort sagt i kulturkampen.

Jeg kan ikke vide, om jeg under normale forhold var blevet sat $i$ dansk eller tysk skole. Mine forældres tøven kan kun tolkes som udtryk for deres usikkerhed. I hvert fald var jeg næsten fyldt 8 , da jeg begyndte i den danske skole i Alslev den 1. april 1946. Jeg har aldrig hørt mine forældre beklage, at jeg kom i dansk skole - selv om dansk skolegang naturligt ville gøre mig dansksindet. De har aldrig forsøgt at påvirke mig i tysk retning eller prøvet at få mig til at skifte skole, heller ikke da det igen blev muligt at åbne tyske skoler indtil gymnasieniveau. Til gengæld kunne jeg på flere af mine kammerater fra tysksindede hjem forstå, at de ikke sjældent hjemme oplevede forældrenes negative reaktioner på, hvad og hvordan der blev doceret $\mathrm{i}$ skolen. Noget sådant har jeg aldrig oplevet.

Et år kom jeg til at gå i Alslev skole, inden vi flyttede i 1947. En gang i løbet af efteråret 1945 gik jeg den kilometer til skolen for at bede om en ABC-bog til selvstudier hos lærer Noesgaard. Ved hjælp af den og Jydske Tidende, der var familiens avishold, lærte jeg at læse. Jeg mindes ikke, at jeg fik nogen systematisk hjælp i den proces, men det er en kendsgerning, at jeg kunne læse, da jeg startede skolen. Jeg havde jo efterhånden også alderen til det. Meget husker jeg egentlig ikke fra det første skoleår. Kun så meget, at der var tale om en enklasset skole, forstået på den måde, at alle elever var samlet i et klasseværelse. Vi sad i tre aldersbestemte rækker, der så på skift blev undervist af enelæreren. Resten arbejdede selvstændigt eller lyttede efter, hvad der foregik $i$ de andre rækker. En slags primitiv gensidig undervisning kan man vel kalde denne form for undervisning, før centralskolerne tog over. Den rummede ganske givet elementer af den differentierede undervisning, som i dag ofte savnes i den strengt årgangsop- 
på at bruge spanskrøret - det sagde også, at i realiteten var hun slet ikke rigtig læreruddannet. Hun var »kun « forskolelærer - en dengang selvstændig lærerkategori. Den næste skole husede 4. og 5. klasserne. Her regerede datidens hr. Møller, der udover at være lærer bestred en funktion, der klart adskilte ham fra de øvrige lærere. Han var nemlig degn ved sognekirken i den oprindelige landsby, Hostrup. Når sandheden skal siges, var Jejsing jo en opkomling, der kun skyldte jernbanen sin eksistensberettigelse. Men positionen som stationsby havde hurtigt gjort Jejsing til centrum i sognet. Her lå mejeriet, samtlige forretninger og altså hele tre skoler. Ved siden af den ansete funktion som degn - det tætteste man i embeds medfør kunne komme på præsten - var Peter Møller den lærer, der skulle forberede de udvalgte elever til det store skisma $i$ deres skoletilværelse og $i$ resten af deres liv. Efter 5. klasse blev eleverne delt $i$ en lille flok, der skulle fortsætte i mellemskolens 4 klasser og derefter enten i realklassen eller i gymnasiet, og det store flertal, der skulle gøre skolen færdig med de resterende pligtige to klasser.

Det store skisma fandt sted ved optagelsesprøven til mellemskolen. Det vil sige, at eleverne i 11-årsalderen blev sorteret i de såkaldt bogligt begavede og de "udpræget praktisk begavede“, som Niels Hausgaard så rammende har kaldt denne restgruppe, der numerisk klart var den største. Størstedelen af samfundets intelligensreserve gik altså tabt i denne sorteringsmekanisme. Heldigvis blev nogle af disse elever samlet op af LO og fik gennem organisationens vidtforgrenede og fagforeningsstyrede uddannelsessystem mulighed for at få realiseret deres evner.

Peter Møller var en hvidhåret ældre herre, der altid var ulasteligt klædt med vest og slips. Han nød en naturlig respekt, der ikke skyldtes umådeholden anvendelse af fysisk afstraffelse. Ganske vist kunne han uddele en habil og rungende lussing, men jeg husker den egentlig mere som undtagelsen end som reglen. Hans faglige kunnen mindes jeg som kompetent, kontant og som noget, man husker.

Positionen som enelærer for fjerde og femte klassetrin - placeret $i$ samme rum - udnyttede han ved fra tid til anden at rydde hele dagens skema til fordel for indlæring af bare én enkelt færdighed. Når vi i regning - som nutidens matematik den gang kaldtes - var nået til for eksempel brøkregning, blev alle timerne den dag brugt til at indøve denne færdighed. Og hvis én dag viste sig at være for lidt, tog vi også den næste med. Dansk og regning var for Peter Møller de 
fundamentale fag, nødvendige for alle de øvrige. Hovedregning mente han var en nyttig færdighed, og hvor havde han ret. Møller nød denne eksercits $i$ alle regningsarter - uden anvendelse af papir, blyant og tavle. Og vi elever blev ferme til denne ovelse. Den dag i dag mindes jeg med stor veneration degnen, når jeg har sammentalt posterne i hovedet, længe ført ekspedienten i bagerforretningen har fået dem tastet ind på regnemaskinen. Også hans dansktimer husker jeg meget tydeligt. Man kan sige, at han opererede med det udvidede tekstbegreb og dyrkede tværfaglig undervisning, længe før disse begreber blev gjort forkromede i ministerielle kommissioner, faglige udvalg, lærerhøjskole og kurser. For ham var det en naturlig måde at præsentere virkeligheden på. Vi sang også meget i Møllers timer naturligvis mange salmer, men også historiske og naturlyriske sange. Så tog degnen violinen ned fra sømmet og akkompagnerede sangen.

Danskfaget var for Møller også naturhistorie, geografi og historie. Projektorienteret undervisning kaldes metoden nok i dag, men jeg er sikker på, at hr. Møller ikke kendte dette fine ord. Han gjorde det bare. Det er ikke nostalgi, jeg her giver udtryk for. Jeg ved ikke, hvor udbredt metoden var i den danske folkeskole i slutfyrrerne, måske var han en enlig svale, måske ikke. Blot onsker jeg at fremhæve, at metoden altså praktiseredes allerede dengang uden tilhørende teoretiske overbygninger. Jeg husker to projekter, som begge mundede ud i - ikke gruppe- men individuelle rapporter. Det ene handlede om landskabsformen hede og det andet om udvandring. Udgangspunktet for begge temaer var Jeppe Aakjærs digt om Ole, der sad på en knold, mens han sang sin udlængsel ud over de sagesløse får. Hver dag gennemgik vi et vers, suppleret med al den historie, naturhistorie og samfundslære, hr. Møller kunne finde på at fortælle. Og det endte med, at knøsen Ole selvfølgelig drog til Amerika, mens fărene gloede efter ham. Alt blev skrevet ned, og det hele endte som genfortælling og dansk stil - de to begreber gik egentlig op i en højere enhed - men udformet som en rapport.

Jeg kom til at gå i alle tre skoler, men i den sidste kun et par måneder, indtil jeg startede i 1 . mellem i begyndelsen af august. Det hang sammen med, at skoleåret på landet skiftede 1. april, der også var skiftedag for de karle og tjenestepiger, der arbejdede i landbruget. I 6. og 7. klasse gik altså de »udpræget praktisk begavede«, dvs. de 1314-årige, der efter konfirmationen »bare skulle ud at bestille noget«. Dem sad hr. Mathiesen altså tilbage med i skole nr. 3. Det var de ca. 


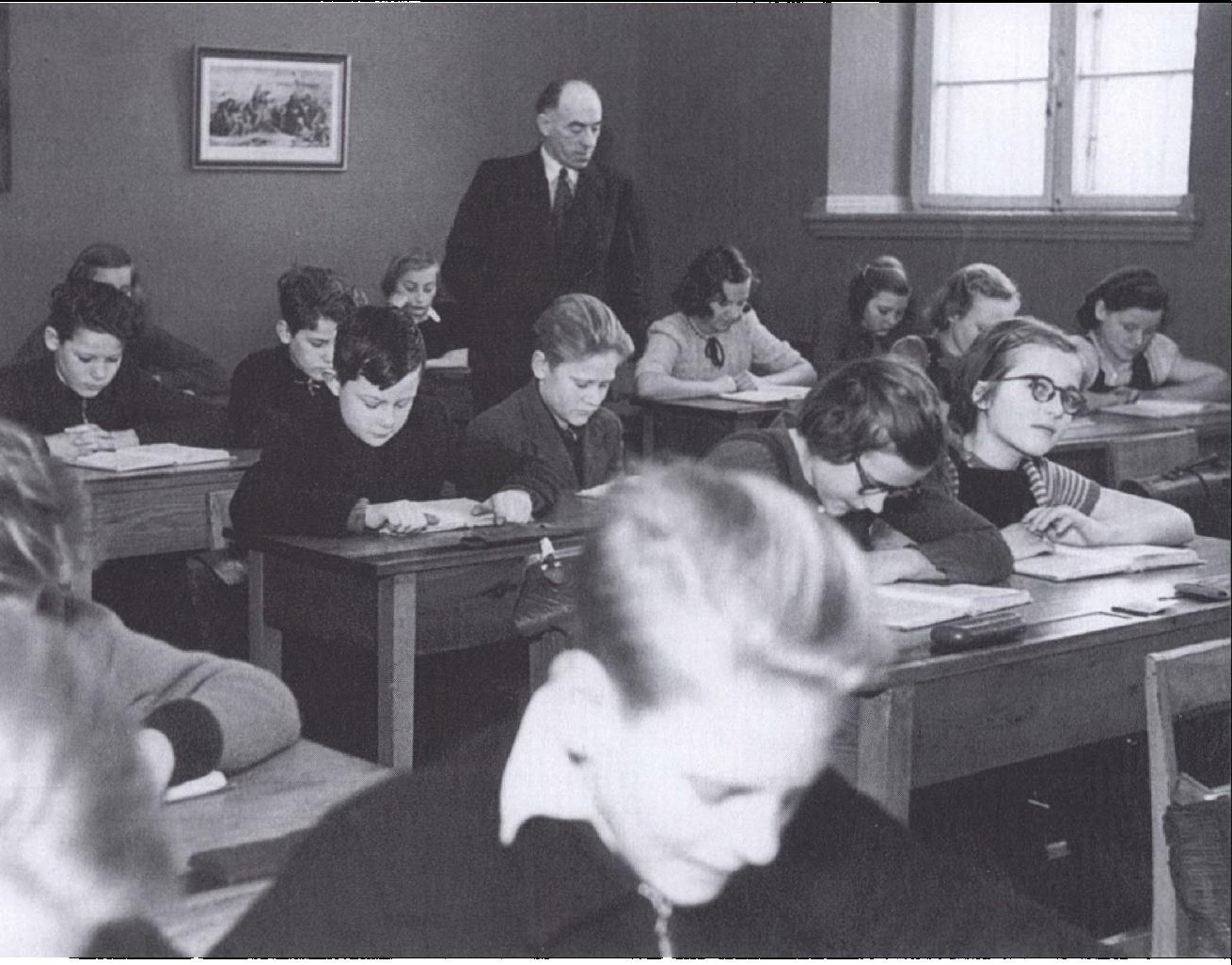

Så andagtsfuld kunne en klasse i mellemskolen sidde anno ca. 1952 - i hvert fald, så lange fotografen gjorde sit arbejde. Kun Karen (Caspersen) kan ikke nære sig for lige at kigge op. Jeg sidder oven $i$ købet med foldede lwander - langst til wenstre på næstnederste rakke. Ved siden af mig sidder Holger (Lorenzen). Fra billedet pi vaggen overvigger Thyra Danebod klassen, mens klasse- og dansklarer Kristensen med alvorsfuld mine foregiver at inspicere en elevs arbejde. Foto i privateje.

$80 \%$ af en årgang, der ikke fik mulighed for eller, som ikke bestod adgangseksamen til mellemskolen i Tønder - enten på Kommuneskolen eller på det ultimativt fineste, Statsskolen.

Degnen er uden tvivl den person, der har haft den mest afgorende indflydelse på min livsbane - for nu at blive lidt højstemt. Ikke blot gav han mig grundlæggende og solide færdigheder i dansk og regning. Men det var også ham, der en gang i 4. klasse henvendte sig til mine forældre og foreslog, at jeg allerede efter denne klasse skulle i mellemskolen i stedet for at vente til efter 5 . klasse, som var det normale. Jeg havde jo alderen til det, men degnen mente også, at jeg nok kunne klare adgangskravene. Denne idé ville mine forældre næppe have fået selv ikke fordi de ikke undte og ønskede mig det bedste, men fordi den lå så langt fra deres virkelighed. Forældres forventninger og krav til deres børns skolegang var endnu i 1950'ernes Danmark mere bestemt af traditioner og sædvaner end af børnenes evner - for slet ikke at tale om 
bevidste ambitioner på børnenes vegne. Mine forældre lyttede naturligvis med stor interesse til degnens forslag - han måtte jo vide, hvad det handlede om. Deres interesse blev naturligvis ikke mindre af, at han tilbød at tage mig med i den lille gruppe af 5 . klasses elever, som han på eget initiativ, uden betaling og udenfor normal skoletid manuducerede i degneboligens private gemakker til den skriftlige del af optagelsesprøven, især i regning. Jeg husker, at vi øvede os på en bunke tidligere opgavesæt. Pludselig fik jeg helt nye skolekammerater.

En gang i forsommeren 1950 cyklede jeg til Tønder for at gå til de skriftlige optagelsesprøver til mellemskolen. I princippet havde der været to muligheder for skolevalg, men i praksis var der kun én. I degnens bevidsthed var Kommuneskolen i Tønder klart at foretrække frem for Statsskolen. Jeg ved egentlig ikke hvorfor, men det lå ligesom i luften, at sidstnævnte var lidt finere på den end førstnævnte. For min far var det afgørende, at bøgerne var gratis på den kommunale skole, mens eleverne selv skulle bekoste dem på den statslige. Denne kendsgerning har givetvis spillet en rolle som social reguleringsfaktor. Jeg husker ikke, at spørgsmålet om den ene eller den anden skole nogensinde var oppe at vende. Så jeg var til optagelsesprøve, dvs. i skriftlig dansk og regning, på Kommuneskolen. Jeg husker ikke noget særligt fra selve prøven, men derimod husker jeg tydeligt dagen efter. Da skulle vi nemlig møde ved middagstid for at få at vide, om vi var optaget alene på de skriftlige prøver, eller om vi skulle ud i en slags opsamlingsheat $\mathrm{i}$ form af mundtlige prøver samme eftermiddag.

Alle aspiranter samledes i skolegården, nogle havde forældre med, mens andre som f.eks. jeg var alene. En lærer kom ud på den ophøjede repos på skolens bagside ned mod alléen. Han læste de navne op, som havde bestået på de skriftlige prøver, og som derfor i princippet kunne tage hjem. Ventetiden var ulidelig, og luften dirrede af nervøsitet - ikke mindst af de tilstedeværende forældres. Måske husker jeg seancen så tydeligt, fordi jeg mange år senere og på en helt anden lokalitet genfandt den beskrevet hos Lise Nørgaard $\mathrm{i}$ hendes pragtfulde og uendeligt morsomme roman Volmer - portret af en samfundsstøtte. Ganske vist er der en generation imellem os, men Lise Nørgaards beskrivelse kan udmærket bruges også på 1950'erne. Et vidnesbyrd om datidens konservative og statiske skolesystem. Men jeg mindes ikke i Tønder nogen, der som Volmer modtog det negative budskab, nonchalant siddende højt oppe i et træ i skolegården, mens han lod sit mødrene ophav, fru ostegrosserer Olsen, alene med skam- 


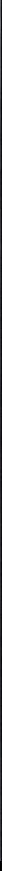

Den professionelle fotograf er tæt på majestætsfornærmelse ved kun at tage dronning Ingrid med på billedet. Det viser i øvrigt Tonder Kommuneskoles samlede larerkorps på larervarelset en gang i begyndelsen af 1950'erne. Siddende for enden af bordet skoleinspektor Johannes Petersen med den uundrærlige cigar og lærer Kristian Kristensen. Skråt bagved skoleinspektoren sto̊r hans kone og bag hende, skråt til hojre hr. Rolfsager. Min kammerat, Kjeld, var hairdt ramt ved, at vi havde hans foraldre, skoleinspektorparret, iflere fag. Jeg havde det ok med dem begge. Foto i privateje.

men nede på jorden, overbegloet af mere heldige borns forældre. Måske har sorteringsmekanismen virket stærkere på Roskildes bedre borgerskab end på ditto i Tønder. Glad cyklede jeg hjem til Tidsholm med det gode budskab om at være optaget i mellemskolen, og mine forældre delte naturligvis min glæde.

Jeg har egentlig aldrig været ked af at gå i skole. Det gælder også de fire mellemskoleklasser $\mathrm{i}$ årene 1950-54. Det forekommer mig, at mellemskolen er blevet uretfærdigt skældt ud for at være "den sorte skole" eller »adgangsbillet til den lærde skole«, læs gymnasiet. Måske har der været markante geografiske forskelle, og måske er det især mellemskolen på de statslige latinskoler, der har fået det dårlige ry. Den rummede naturligvis kun en brøkdel af en årgang, og det var selvfølgelig en social fejl. Men som skoleform havde den mange af de kvaliteter, som de rådende pædagogiske vinde efter alle solemærker i dag onsker tilbage til skolen - men nu udspredt på alle elever. I 1950'ernes mellemskole fik de udvalgte elever grundlæggende kundskaber og færdigheder - ikke 
blot i dansk og regning/matematik, men også i så forskellige fag som fysik, geografi, naturhistorie, fremmedsprog og historie. Jeg fik en paratviden, som jeg mener, jeg har glæde af den dag i dag. Måske var der for mange årstal, kongerækker, geografiske blindkort og navne på byer, floder, have, bugter mv. eller for mange dyre- og plantenavne. Men der er på den anden side tale om en aldersgruppe, som er uhyre motiveret og modtagelige for facts og udenadslære. Blandt lærerne husker jeg Kristian Kristensen, en ældre og meget besindig mand, som vi havde i dansk og historie. Hos ham lærte jeg grammatisk og systematisk at analysere en sætning, at stave korrekt og sætte tegn. Han gav mig også - i hvert fald den bevidste interesse for faget historie. Jeg kan huske, at jeg på eget initiativ og til eget brug derhjemme begyndte at lave små sammendrag af lærebogens historiske stof og koble det sammen med, hvad jeg i øvrigt havde fået fortalt.

I mellemskolen kom jeg også for første gang til kongens København. Hele klassen skulle fjorten dage på »Den nordiske Lejrskole“ ved Hillerød. En svensk skoleklasse fra Bromma ved Stockholm var samtidig på skolen. Det hele skete naturligvis i det nordiske samarbejdes navn - på det overordnede plan. Jeg må have taget de fine ord meget alvorligt forelskede mig i hvert fald voldsomt i en flicka med det skønneste mørke hår. Meget ærbart naturligvis og meget på afstand. Men følelserne og de pubertære hormoner ruskede min uskyldige krop og sjæl. Skolen var i øvrigt en ægte lejrskole - med streg under skole. DSB havde efter gældende regler givet frirejse. Og hver dag havde nye opgaver. Besøg på Frederiksborg Slot, tur til Helsingør med besøg på kloster og Kronborg, teglværksbesøg - og så det ultimativt spændende: Til København med biograftur og friaften i Tivoli. Filmen husker jeg ikke - men derimod, at biografen var Palladium. Og før filmen kom der et flygel med tilhørende pianist op af gulvet - han spillede og forsvandt igen med instrument i gulvet. Det var fascinerende og er i hvert fald bevaret i hukommelsen. Efter hvert besøg skulle der skrives rapport, før fraterniseringen med de øvrige nordboere kunne begynde.

Jeg husker fra mellemskolen også den dynamiske og sympatiske Carl Rolfsager, som vi havde i regning/matematik og naturhistorie. Jeg var allerede blevet en god regner - ikke mindst hovedregner hos degnen i Jejsing, men i naturhistorie begyndte jeg at botanisere derhjemme. Afgjort inspireret af lærer Rolfsager og hans undervisning. Udstyret med Den lille Flora og med en lille taske på ryggen drog jeg ud i naturen omkring gården derhjemme for at indsamle og 
navnebestemme planter ud fra bladform, antal støvdragere, kronblade og andre vigtige kendetegn. Hjemme blev blade og blomster lagt $\mathrm{i}$ pres mellem to brædder og noget specielt trækpapir og efter tørringen anbragt $i$ et herbarium. Desværre rejste Rolfsager efter et par år i vores klasse for at blive skoleinspektør et andet sted.

Også skoleinspektøren, Johannes Petersen, husker jeg tydeligt og med glæde. Han kunne virke bister og bøs, og mange elever var givetvis bange for ham - $i$ øvrigt alle skoleinspektørers image og skæbne, desværre. Men jeg blev bedste ven med hans søn Kjeld, og det muliggjorde, at jeg også lærte hans far at kende fra en anden og mere privat vinkel. Den kendsgerning, at hans søn gik i min klasse, var formodentlig afgørende for, at skoleinspektøren viste den en ganske særlig interesse og bevågenhed. Han overtog klassen i regning og matematik efter Rolfsager, og jeg tror, det var i 4. mellem, at Johannes Petersen opdagede, at tyskundervisningen ikke gik for godt i vores klasse. Resolut overtog han selv undervisningen og fik i sandhed rettet op på klassen. Jeg husker ikke engang, hvem han satte fra bestillingen, men jeg husker, at klassen fik lært noget tysk - både mundtligt og skriftligt. Ligeledes i matematik.

Det var en æressag for skoleleder Johannes Petersen hvert år at kunne sende et antal dygtige og energiske elever fra 4 . mellem på gymnasiet. Og vel at mærke elever, der fagligt kunne klare sig - sammenlignet med dem, der hele tiden havde gået på Statsskolen - som han i øvrigt selv var dimitteret fra. Derfor stod han også personligt for undervisningen til den lille latinprøve - den kommunale skoles eneste akademiske islæt. Lærebogen var naturligvis Mikkelsens udødelige begynderbog, og de grammatiske remser blev øvet og lært sammen med lærebogens pragtfulde tekster som f.eks.: Hvor er far? Svinet roder i haven. Min ven Kjeld var i sandhed en plaget sjæl - at have faderen til latin, matematik og tysk samtidig med, at denne også var skolens leder. Det kunne man da kalde at være en lus mellem to negle - faderens konstante ånde $\mathrm{i}$ nakken og samtidig skydeskive for kammeraternes berettigede eller uberettigede utilfredshed med dette eller hint - men i hvert fald inspektoren. Og som om det ikke var nok, havde vi Kjelds vidunderligt milde mor som lærer i engelsk gennem hele mellemskolen. Jeg husker, at hun insisterede på, at vi elever live skulle opleve kroningen af den engelske dronning Elizabeth 1. i 1952. Jeg kan endnu den dag i dag høre hende fortælle om den umådeligt tunge krone og det store imperiale og nationale ansvar, der helt bogstaveligt skulle placeres på den unge og spink- 
le pige. Da skolen naturligvis ikke havde eget fjernsyn, lejede hun resolut et ude $\mathrm{i}$ byen, og vi sad klistret til den sort-hvide skærm og fulgte intenst hele seancen i Westminster Abbey.

Jeg tilbragte mange gode stunder sammen med Kjeld; jeg overnattede $\mathrm{i}$ hans hjem f.eks. efter fester på skolen, og han besøgte mig hjemme på Tidsholm. Jeg har aldrig været god til at fastholde eller dyrke venskaber. Egentlig en stor fejl - al den stund, mange af venskaberne dog er blevet stående skarpe og væsentlige $\mathrm{i}$ erindringen. Med skolekammerater går det vel ofte sådan, at de efter skolen vælger vidt forskellige arbejder eller studier og dernæst stifter familie - $\mathrm{i}$ alle funktioner opstår nye relationer, hvoraf nogle fører til nye venskaber. Kjeld valgte $i$ første omgang seminarievejen, havde forskellige lærerjobs og tog senere sideløbende en overbygning i form af en kandidatuddannelse $\mathrm{i}$ historie fra Danmarks Lærerhøjskole og afsluttede sit arbejdsliv som lektor på Herning Seminarium. I dag - i vores pensionisttilværelse - har vi genoptaget relationerne fra dengang. Uden egentlig at opleve, at der siden er gået næsten tres år.

\section{Statsskolen}

Overgangen fra mellemskolen og til gymnasiet husker jeg som ret barsk - på mange fronter. Det havde ligget i luften, at jeg skulle vælge den matematiske linje. Det skyldtes vel primært, at jeg havde været ret skrap til regning og matematik i mellemskolen. Men først og sidst var årsagen nok den banale, at også de andre, der kom fra Kommuneskolen, valgte den matematiske linje - givet under indflydelse af Johannes Petersen. På trods af, at jeg i mit professionelle arbejde fik mere brug for sprog og humaniora end matematik, fortryder jeg ikke valget. I 1954, hvor jeg kom i 1.g., er der næppe tvivl om, at den matematiske linje ved også at tilbyde to fremmedsprog - det ene som fortsættelses- og det andet som begyndersprog - gav den fagligt set bredeste almene undervisning. Først senere kom der et strejf af naturvidenskab ind i den sproglige linje.

Hvorfor oplevede jeg overgangen til gymnasiet som barsk? Der er flere grunde. For det første havde mange af kammeraterne i 1.g. gået i mellemskolen på Statsskolen, andre var omgængere - begge kategorier kendte lærerne, og lærerne kendte dem. De satte derfor naturligt nok dagsordenen og førte ordet - $i$ hvert fald i den svære overgangsfase. Lærernes tilgang til såvel stof som elever var helt tydeligt en 
anden på Statsskolen - og der blev ikke gjort noget bevidst for at lette overgangen. Pludselig blev vi opfattet - ofte i eklatant strid med virkelighedens verden - som voksne og selvstændige mennesker, der forventedes at spørge, når der var noget, vi ikke forstod eller gerne ville have uddybet. Og som havde og luftede egne meninger. Lærebogen var pludselig ikke verdens faste og eneste omdrejningspunkt, der rummede den hele og fulde sandhed. Det forventedes, at vi stillede spørgsmål, som rakte ud over lærebogens stof. Det gjaldt naturligvis ikke alle lærere, men alligevel lå det ligesom i luften hos de fleste. $\mathrm{Og}$ det blev understreget, at gymnasiet jo havde en dobbeltfunktion. Den skulle give det, der udefinerbart kaldtes almen dannelse - og skulle desuden forberede til videregående studier. I 1950'ernes sprogbrug betød videregående studier hverken faglige eller mellemlange studier - det betød entydigt højere uddannelser, på universitet, polyteknisk læreanstalt, tandlægehøjskole osv.

Men det mest overraskende for mig var pludselig at opdage, at vi elever havde vidt forskellig baggrund - socialt, økonomisk og kulturelt. Det havde jeg egentlig ikke bemærket - hverken i underskolen eller i mellemskolen. Selv om forskellene selvfølgelig også havde været der. Jeg har aldrig bevidst oplevet, at der fra lærernes side blev giort forskel - begrundet $i$, hvilket socialt miljø man kom fra. Jeg vidste da godt, at bøndergårdene havde forskellig størrelse, og at andre forældre var købmænd, håndværkere, arbejdere, lærere osv., men jeg mindes ikke, at jeg gik op i eller blev mindet om, hvilke implikationer disse forskelle kunne have. Anderledes i gymnasiet, hvor elevernes sociale spektrum blev bredere. Ikke fordi det var noget, der eksplicit blev sagt eller blot antydet. Det var bare noget, der indirekte fremgik af så mange ting. Pludselig gik det op for mig, at der var hjem, hvor verdenssituationen og generelt politiske emner blev diskuteret og vendt og drejet ved morgenbordet, og hvor man holdt sig orienteret gennem andre medier end Jydske Tidende eller en skrattende batteridreven radio. Elever fra disse hjem var straks med og kunne reagere, når f.eks. historielæreren startede timen med at henvise til en aktuel begivenhed - enten på Christiansborg eller ude i den store verden. I sådanne situationer oplevede jeg virkelig de sociale og intellektuelle forskelle i klassen. Og fik vel også motivation til at få indhentet det forsømte.

Mine startvanskeligheder skal imidlertid ikke overskygge min glæde ved de tre gymnasieår. Jeg trivedes der - ikke mindst betinget af de udfordringer, der lå i muligheden for at læse bøger og tekster, der 
lå udenfor pensum. Jeg lånte mange bøger på biblioteket - måske især bogtitler, som lærerne anbefalede i timerne. Men jeg fandt også hurtigt ud af, at hverken min lyst eller mine evner gik i retning af matematikkens rene logik eller fysikkens og kemiens eksperimentelle verdener. Fysikken kunne til nød gå an, især hvis faget antog en historisk og humanistisk vinkel. Men generelt manglede disse to fag i mine øjne at handle om mennesker - om store følelser, begivenheder, de store linjer - kort sagt om alt det, der er forbundet med menneskets gøren og laden i fortid og nutid. Det fandt jeg til gengæld i fagene dansk og historie, suppleret med oldtidskundskab. Hvilke bøger søgte jeg på biblioteket? Alt muligt, men en forfatter som H.C. Branner var jeg meget optaget af. Måske, fordi han havde så godt et tag på menneskers indre, deres skjulte og mystiske sider. Nordahl Griegs klassiker Ung må verden endnu være - om hans oplevelser i 30'ernes Sovjetunionen, slugte jeg. Ligeledes Sigurd Hoel og Aksel Sandemose var gode og varige bekendtskaber. Også faget fransk bekom mig vel sikkert, fordi vi her havde en forholdsvis ung lærer, Ove Quistorff, der gjorde faget til mere end grammatik og gloser. Jeg fik ug $\div(=11)$ til studentereksamen. Jeg nævner det kun, fordi karakteren i netop fransk med al sandsynlighed var afgørende for, at jeg i min soldatertid kom til at beskæftige mig med russisk. På en måde blev denne tilfældighed dermed også bestemmende for hele mit arbejdsliv.

Det er utroligt, hvor mange udviklingslinjer i et menneskes liv der i virkeligheden starter i tilfældigheder. Min vej til Rusland startede med NATO - så kort og kontant kan det siges. Mens jeg forberedte mig til studentereksamen ved Tønder Statsskole i foråret 1957, dumpede et brev ind gennem brevsprækken, som det gjorde hos alle andre unge mænd i Danmark i samme situation. I brevet tilbød Forsvaret de kommende studenter det år mulighed for at lære russisk sideløbende med, at de aftjente deres værnepligt. Også det danske militær havde nu opdaget - eller også havde NATO dikteret - det geniale $i$ at have folk, der kunne tale fjendens sprog. Jeg indsendte en ansøgning, men skænkede den egentlig ikke mange tanker i de følgende måneder. De var fuldt optaget af forberedelse til eksamen, selve studentereksamen og den påfølgende halve snes dages heftige festivitas. Dertil kom, at jeg for længst havde søgt om at starte aftjeningen af min værnepligt snarest muligt efter eksamen, og jeg havde såmænd også modtaget indkaldelse til at give møde ved 9. Regiments rekruttjeneste i Søgaardlejren kl. 12 den 2. juli 1957, mens den ansøgte uddannelse først begyndte to måneder 
senere. En usikker ansøgning kunne naturligvis ikke bruges som begrundelse for en ansøgning om senere indkaldelse. Men jeg blev optaget, og jeg ved, at den person i Forsvarsministeriet, der kom til at gennemgå ansøgningerne og reelt traf afgørelsen, var en cand.mag. med fransk som hovedfag. Jeg ved også med $99 \%$ sikkerhed, at hans hovedkriterium for optagelse netop var karakteren i fransk

Hvorfor havde jeg søgt om at aftjene værnepligt, når der var mulighed for at søge om udsættelse til efter afsluttet uddannelse? Det var ikke, fordi jeg var usikker på, hvad jeg ville studere. Allerede tidligt i gymnasiet havde jeg som nævnt besluttet mig for historie som hovedfag og dansk som bifag. Det var heller ikke, fordi militæret ligefrem trak i mig - min viden om det var yderst begrænset, og der var ingen stolte militære traditioner i min familie. En farbror var faldet i 1. Verdenskrig, men det var som tvungen værnepligtig i den tyske, kejserlige hær, og min far var - nu som dansk statsborger efter Genforeningen i 1920 blevet »kasseret som uegnet til al krigstjeneste«, som han selv lidt stolt udtrykte det. Udsigten til at blive kasseret på sessionen var i 1950'ernes Danmark yderst begrænset. NATO var endnu ung, befolkningen skulle efter 80 års neutralitet vænnes til at springe soldat, og Den kolde Krig var en levende realitet - så der var intet mærkeligt $i$, at medlemslandene stræbte efter at få så mange i trøjen som muligt. Ganske vist florerede der drabelige historier om, hvad man kunne gøre ved sig selv før sessionsbehandlingen for at fă hjertet til at hoppe og danse eller gøre platfoden endnu mere plat - for på den måde at blive fritaget for militærtjeneste. Men nøgternt betragtet måtte man også konstatere, at sådanne krumspring yderst sjældent $i$ virkelighedens verden blev ført ud i livet eller havde ført til kassation. Mit eneste motiv for hurtigst muligt at komme ind var efter min bedste hukommelse og overbevisning, at det blot gjaldt om at få militærtjenesten overstået så tidligt som muligt. Den uddannelse, jeg havde valgt, gav jo ikke som f.eks. læge-, tandlæge- eller ingeniøruddannelsen adgang til at aftjene på særlige ordninger. Senere kunne militærtjenesten også let vise sig at komme i vejen for de jobmuligheder, der måtte vise sig.

Danmark havde i 1949 brudt med mere end 80 års neutralitet, eller skal vi lidt mere realistisk sige brudt med sin sydvendte udenrigspolitik. Regering og Rigsdag havde meldt landet ind i NATO ved organisationens dannelse. Det vil sige, at vi nu var aktive deltagere $i$ en forpligtende alliancepolitik, der ved også at omfatte USA var transatlantisk. Min viden om Rusland var minimal, og gymnasiet bidrog ikke væsent- 
ligt til at ændre dette triste billede. Min historielærer, lektor Otto Høyer, var en meget aktiv hjemmeværnsmand, så hans storpolitiske holdninger og især til Sovjetunionen var krystalklare: Dens ultimative mål var ifølge de revolutionære fædre og Stalins praksis verdensrevolutionen, Den kolde Krig var skabt ene og alene af hans politik i Europa i almindelighed og specielt overfor de østeuropæiske lande. Den blev endvidere holdt ved lige af en stribe grusomme handlinger mod dem. Kuppet i Prag og den kommunistiske magtovertagelse i Tjekkoslovakiet i februar 1948, Berlin-blokaden fra november 1948 og til maj 1949 samt de forskellige skueprocesser mod national-kommunister $\mathbf{i}$ forskellige østeuropæiske lande var pejlemærker i den holdning til Den kolde Krig, som vi gymnasieelever blev præsenteret for i historietimerne.

Og så kom i 3.g. - i november 1956 - den ultimative bekræftelse af sovjetledelsens skumle hensigter: Den ungarske Opstand og Sovjetunionens militære nedkæmpelse af den. I og for sig var der jo ikke noget direkte forkert $\mathrm{i}$ min historielærers udlægning af begivenhederne. Tværtimod kan man sige, at det var al ære værd, at han overhovedet drøftede samtidshistoriske, for ikke at sige helt dugfriske, emner med sine elever. Det var absolut ikke almindeligt i 1950'ernes gymnasieskole. Det, man kan stille spørgsmålstegn ved, var den totalt manglende nuancering af synspunkterne, som var så karakteristisk for 1950'ernes fastlåste og sort-hvide holdninger til, hvad der skete på den storpolitiske scene, og som min historielærer absolut ikke var alene om. Ikke et ord om den geopolitiske lære, Sovjetunionen måtte drage af Verdenskrigens erfaringer eller for så vidt af århundreders oplevelser af europæisk storpolitik. I det hele taget var 1950'erne ikke de finere nuancers årti. Ovenstående bemærkninger skal på ingen måde overskygge min historielærers kvaliteter - både som historiker og underviser. Han vedligeholdt og nærede min interesse for historie $\mathrm{i}$ en grad, så jeg aldrig kom i tvivl om, at det var det fag, jeg ville studere.

Ellers er der specielt en lærer fra min gymnasietid, som jeg især husker med stor veneration. Det er Anders Feilberg Jørgensen, der ved siden af at være skolens rektor også blev min dansklærer. I sidstnævnte rolle optrådte han for første gang i sin karriere i vores klasse, og jeg er sikker på, at det også blev sidste gang. Feilberg var først og fremmest historiker, så derfor er det ikke overraskende, at hans danskundervisning $i$ høj grad og til min store glæde fik en klar historisk vinkel. Udover det faglige er der i øvrigt tre ting, som jeg især forbinder med Feilberg Jørgensen, og de har primært at gøre med 


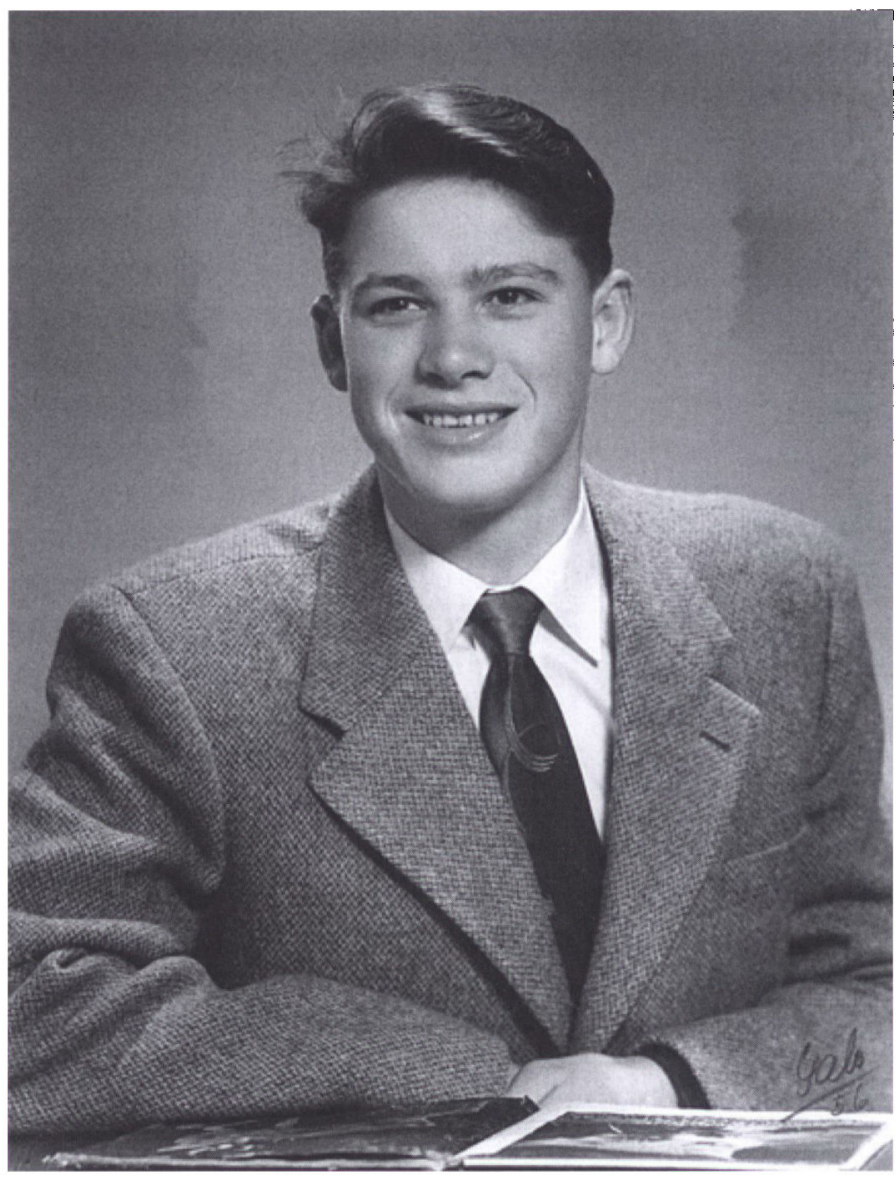

Ung mand hos fotografen omkring 1955. Jeg har lige fäet nyt toj, så gladen er til at tage og fole på. Det skete ikke så ofte, at jeg blev ekviperet fra top til tå -med slips, hvid skjorte, tweedjakke og morke bukser. Fotografen Arne Gabs har oven i købet som en anden kunstner signeret og dateret billedet. Hans Nebengeschäft var vejrprofet - ikke dem med friske vejrudsigter fra time til time, men landskendt for sine langtidsprognoser. Der blev lyttet til, hoad Gabs profeterede - min far var en af hans trofaste proselytter. Foto $i$ privateje.

hans funktion som skolens rektor. For det første lagde han stor vægt på, at gymnasieskolens elevprofil socialt i højere grad kom til at afspejle befolkningens reelle sammensætning. Min fysiklærer, Kjeld Ejrnæs, spildte ikke nogen mulighed for at skose os, hvis vi i skolearbejdet havde gjort os bemærket på en mindre heldig måde. Og hans omkvæd var, at gymnasieelever ved kun at omfatte sølle $5 \%$ af en 
årgang havde en forpligtelse til at strenge sig an. Feilberg havde derfor en ganske særlig interesse i de elever, der kom fra såkaldt ikkelæsevante miljøer - en interesse, som jeg i høj grad nød godt af.

Det andet forhold, jeg vil fremhæve hos Feilberg, har at gøre med den nationale problematik - altså med forholdet mellem dansk og tysk. Da jeg begyndte i gymnasiet, var der gået mindre end 10 år fra Tysklands civilisationssammenbrud i 1945. Siden Genforeningen i 1920 havde Tønder Statsskole stået som et fyrtårn og som garant for danskheden i grænselandet, og denne rolle var ikke blevet mindre i årene efter besættelsen. Rollen som danskhedens vagthund og bevarer havde den tidligere rektor Jakob Randrup spillet med bravur ikke mindst under den tyske besættelse. Det var derfor en stor og langt hen ad vejen en umulig opgave, Feilberg arvede, da han i $1954-$ samme år, som jeg startede i gymnasiet - flyttede fra Frederiksborg Statsskole til Tønder. Som præstesøn, født i Skærbæk og student fra Tønder Statsskole, vendte han hjem til grænselandet. Og med et håb om, at krigstidens og besættelsestidens had kunne afløses af fred og forsoning med et Tyskland, der nu alvorligt og med de vestlige sejrherrers hjælp provede at bygge et demokrati.

Jeg ved, at Forbundsrepublikkens første præsident fra 1949 til 1959, Theodor Heuss, der allerede 1932 i bogen Hitlers Weg havde advaret mod Hitler, i Feilbergs øjne var garant for seriøsiteten i de tyske demokratiske bestræbelser. Og dem skulle vi efter Feilbergs mening støtte på enhver måde. Men det viste sig ikke velset $i$ lokalbefolkningens øjne og heller ikke i den lokale presses, men til gengæld i bagklogskabens lys uhyre fremsynet, at rektor i forbindelse med de skelsættende dansk-tyske grænselandsaftaler i $1955 \mathrm{og}$ med ministeriets fulde billigelse foreslog en elev- og lærerudveksling med en gymnasieskole i Hamborg. Udvekslingen blev gennemført og gentaget de følgende år.

Og endelig det tredje forhold har at gøre med Feilbergs undervisningsmetoder. Han lagde stor vægt på, at vi elever formulerede egne meninger om stoffet. Det skulle ikke blot være et udenadlært pensum, men derimod præget af personlige holdninger - der var med andre ord tale om en metode, der bestemt ikke var almindelig i 1950'ernes langt hen ad vejen skolastiske danske gymnasieskole. Vi elevers meninger om et litterært værk skulle ikke blot være hentet i et kommentarhæfte, men derimod i teksten. Jeg har lært meget om tekstnærhed af min dansklærer i gymnasiet. En metode, der 10-15 år senere blev det nye mantra $i$ al danskundervisning. 

blev jeg i årene 1964-73 kollega med ham, men det er en helt anden historie.

Der var en begivenhed fra min gymnasietid på Tønder Statsskole, som jeg husker meget tydeligt, og som dengang bragte et frisk pust ind i den daglige trummerum, gjorde verden større, og som i bakspejlet skulle komme til at pege frem mod mit voksenliv og -arbejde. Det har været en gang i løbet af 1956, men før Ungarn-krisen i november måned, at skolen fik besøg af min senere professor Ad. StenderPetersen fra Aarhus Universitet. Han skulle primært forelæse om aftenen i den lokale afdeling af Folkeuniversitetet, og da rektor var dens formand, har det været nærliggende for ham at bede gæsten om at holde et foredrag - også i skoletiden og på skolen. Jeg overværede begge arrangementer, og de må have gjort et dybt indtryk på mig, for jeg husker såvel emnerne som indholdet ganske tydeligt. På skolen talte Stender-Petersen om Nikolaj Gogols roman Døde sjæle, og om aftenen var emnet "Sovjetunionen efter Stalin «, der var død i 1953. Jeg gik oven i købet nogle dage senere i boghandelen for at købe eller bestille den pjece, som Folkeuniversitetet den gang altid lod trykke i forlængelse af forelæsningerne. Jeg har den nemlig den dag i dag. På det tidspunkt kunne jeg ikke vide, at Stender et par år senere skulle blive en af mine første lærere på Aarhus Universitet.

Sidste skoledag på gymnasiet husker jeg kun for en ting. Jeg er heller ikke sikker på, at der skete så forfærdeligt meget. Men jeg husker, at vi elever - sølle 16 matematikere og 9 sproglige-om aftenen tog toget fra Tønder $\mathrm{H}$ over landegrænsen og til Süderlügum. Jeg husker også, at vi der sad mutters alene på et værtshus, drak nogle drinks til de lave tyske priser og tog toget igen - nu den anden vej. En strækning på i alt omkring $12 \mathrm{~km}$ hver vej. Det var en uhyre beskeden sidste skoledag. Vel at mærke, når man sammenligner med nutidens sofistikerede og opulente forestillinger i den anledning. Eksamenstiden med dens skriftlige og mundtlige prøver adskilte sig til gengæld ikke væsentligt fra, hvordan den til alle tider har formet sig. Såkaldt læseferie, eksamensdage, nervøsitet, glæde, sorg - det er vel hovedingredienserne i en læseferie til alle tider. Til gengæld stod der ikke horder af mere eller mindre nervøse forældre, bedsteforældre, søskende og kammerater klar med studenterhue, blomster, champagne, kransekage mm., når den nervøst smilende eksaminand kom ud fra sidste fag. Rektor eller en stedfortræder satte huen på hovedet - det var det hele, men vi var jo også en årgang på kun 25 nybagte studenter. 
Den 1. april 1957 var vi flyttet fra Tidsholm. Gården var solgt, og mine forældre flyttede til asfaltlivet i Tønder. Jeg kan huske min fars glæde ved at sige farvel til landmandslivet - egentlig mærkeligt på baggrund af, at det havde været hans og hans forfædres liv altid. Men han så frem til at cykle rundt $\mathrm{i}$ Tønder, snakke med folk og i øvrigt være fri for landlivets konstante usikkerhed. Jeg er sikker i min sag, når jeg siger, at hverken min far eller mor længtes tilbage til livet på Tidsholm. Jeg gjorde det heller ikke, fik også dårligt tid til det eksamenslæsning, eksamen og aftjening af værnepligten ventede forude i en stram tidsfølge. Den 2. juli 1957 tog jeg toget til Lundtoft station - et gudsforladt trinbræt mellem Tinglev og Sønderborg. Her blev jeg sammen med mange andre i samme situation modtaget af en flok af højträbende og gestikulerende sergenter.

Et nyt kapitel i mit liv skulle til at begynde - et kapitel med værnepligt, studier, familiestiftelse og børn. Men også med nye udfordringer, større udsyn og horisont - og med det fulde ansvar for eget og andres liv. Barndommens kyst fortonede sig mere og mere. Som 1819-årig er ens interesse for barndommen og dens fænomener til at overse. Det blev oplevet som noget, der heldigvis var overstået. Nu var det fremtiden, der bankede på for at blive erobret. Jeg husker en pudsig episode fra mit tjenesteophold på flyvestation Skrydstrup. Jeg var $\mathrm{i}$ officersmessen blevet gode venner med en ligeledes tjenstgørende læge og spurgte ham en gang, om man efter aflagt embedseksamen ikke holdt nogle orgier, der stillede festlighederne efter bestået studentereksamen helt i skyggen. Stilfærdigt røbede han for mig, at det egentlig gik meget fredsommeligt til. Jeg undrede mig meget over svaret og forstod det egentlig først, da jeg selv var blevet kandidat i Århus. Som nybagt student mente man at være færdig, at have erobret hele verden. Og det skulle fejres. Som nybagt kandidat havde man opdaget, hvor lidt man egentlig kunne. Erobringslysten var blevet mere konkret og beskeden. Barndommens kyst kunne atter skimtes. Og i løbet af et liv er den atter kommet helt tæt på.

Thomas Petersen er født i 1938, student fra Tønder Statsskole 1957. Værnepligt 1957-59. Cand.mag. 1968 i historie og russisk fra Aarhus Universitet. Årsvikar i russisk og historie Århus Statsgymnasium 1964-73. Kandidatstipendiat ved Aarhus Universitet 1968-70. Amanuensis 1970-72. Lektor ved Slavisk Institut, AU 1972-2000. Forskning og undervisning i Ruslands og Sovjetunionens historie. 